\title{
Os Meninos de Rosa: sobre vítimas e algozes, crime e violência*
}

Roberto Efrem Filho**

\section{Resumo}

Este artigo objetiva tratar das aproximações e dos distanciamentos entre duas figuras fundamentais para os processos de Estado, as vítimas e seus algozes. Estruturando-se a partir de dois momentos etnográficos distintos, o momento da entrevista com Rosa, uma militante de Direitos Humanos e mãe de Gabriel, um menino cujo assassinato teria sido motivado por homofobia, e o momento da sessão do tribunal do júri que levou à condenação dos dois acusados por esse homicídio, este texto tematiza as "reciprocidades constitutivas" entre relações de gênero, sexualidade, classe, racialização, geração etc. que compõem as narrativas e experiências muito próximas da vítima e dos algozes e fazem de todos eles alvos prioritários dos processos mais amplos de criminalização e violência. Considerando, ainda, a relevância das noções de "crime" e "violência" na contextura das formas estatais de inteligibilidade, este texto aborda, também, o lugar do crime no interior daquelas reciprocidades constitutivas, distinguindo-o do objeto central dos confrontos em que Rosa se encontra implicada, a violência, então compreendida como o excesso, o inadmissível narrativo que, contraditoriamente, compõe a possibilidade de reconhecimento das vítimas, os meninos de Rosa.

Palavras-chave: Violência, Crime, Vítima, Algoz.

\footnotetext{
" Recebido em 6 de agosto de 2017, aceito em 4 de setembro de 2017.

*** Professor do Departamento de Ciências Jurídicas da Universidade Federal da Paraíba (UFPB), João Pessoa-PB, Brasil. robertoefremfilho@yahoo.com.br 
The Rosa's Boys: About Victims and Executinioners, Crime and Violence

\begin{abstract}
This article aims to discuss about the approximations and distances between two fundamental figures of the State processes, the victims and their executioners. Structured by two distinct ethnographic moments, the moment of the interview with Rosa, a Human Rights activist and Gabriel's mother, a boy whose murder would have been motivated by homophobia, and the moment of the jury trial session that took the two defendants for Gabriel's death to condemnation, this text brings as subjects the "constitutive reciprocities" among genre relations, sexuality, class, racialization, generation etc. that compose victims and executioners' narratives and very close experiences and make them all primary targets for the wider processes of criminalization and violence. Considering yet the importance of the notions of crime and violence to the contexture of the Statal forms of intelligibility, this text also approaches the crimes' place inside those constitutive reciprocities, distinguishing it from the core objects of the fights Rosa is implicated in, and the violence comprehended then as the overmeasured, the inadmissible narrative that contradictorily composes the possibility of recognition of the victims, Rosas's boy.
\end{abstract}

Keywords: Crime, Violence, Victim, Executioner. 


\section{1."Eles mataram Gabriel. E ele era homossexual": apresentação}

[13 de novembro de 2013, noite de quarta-feira]. Eu ocupava uma das cadeiras do auditório do antigo prédio da Faculdade de Direito da Universidade Federal da Paraíba, com o caderno do diário de campo às mãos, quando avistei Rosa na plateia. ${ }^{1}$ Havia anos que eu não a via, desde a época em que partilhávamos o cotidiano das reuniões do Movimento Nacional de Direitos Humanos no Recife, em meados da primeira década dos anos 2000. Agora, ela e eu compúnhamos a audiência de um seminário, organizado por professores e estudantes ligados ao Centro de Referência em Direitos Humanos da UFPB, acerca do "caso Manoel Mattos", o primeiro caso de federalização de uma "grave violação de Direitos Humanos" no país. ${ }^{2}$ Manoel havia falecido em 24 de janeiro de 2009. Advogado, dirigente do Partido dos Trabalhadores e ex-vereador de Itambé, uma cidade de pouco mais de 36 mil habitantes localizada na fronteira entre Pernambuco e Paraíba, Manoel dedicou parte significativa de sua militância política à denúncia das violências que forjam aquela região. Dentre essas violências estariam, segundo o próprio

\footnotetext{
1 Neste texto, os nomes próprios ficcionalizados se encontram em itálico, a exemplo de Rosa, Gabriel e Santana. Também estão em itálico as categorias êmicas e as expressões sob rasura, como homofobia, exploração sexual e grupos de extermínio.

2 A priori de competência da Justiça Estadual, a morte de Manoel seria objeto de uma ação judicial corriqueira na comarca do município de Pitimbu. No entanto, os esforços de organizações de Direitos Humanos como a Dignitatis e a Justiça Global, dos familiares de Manoel, sobretudo de Nair Ávila, a sua mãe, e de importantes parceiros políticos junto, por exemplo, à seccional pernambucana da Ordem dos Advogados do Brasil, ao Conselho de Defesa da Pessoa Humana e ao Ministério Público Federal, possibilitaram, no ano de 2010, a conquista da federalização. Como dito, o "caso Manoel Mattos" foi o primeiro caso de federalização de uma "grave violação de Direitos Humanos" no país. Apesar da possibilidade desse procedimento se achar prevista desde 2004 no art. 109 da Constituição Federal, até que a morte de Manoel chegasse ao Superior Tribunal de Justiça nenhum caso havia sido federalizado.
} 
Manoel $^{3}$, as ações de grupos de extermínio compostos por policiais civis e militares, agentes penitenciários, vigias ou seguranças privados irregulares, pistoleiros, jagunços e mandantes. Naquele dia 24, Manoel Mattos estava com amigos em Pitimbu, uma praia do litoral sul paraibano, quando sofreu dois tiros fatais. As investigações policiais concluíram que as balas foram desferidas por um sujeito ligado a um soldado denunciado seguidas vezes por Manoel como integrante desses grupos.

Assim como Manoel, Rosa também dedicara grande parte de seus dias à defesa de Direitos Humanos e a denúncias de violências praticadas por grupos de extermínio, mas principalmente por aqueles existentes em Santana, o bairro periférico recifense em que ela morou durante décadas. Sua presença no auditório da Faculdade de Direito na noite de 13 de novembro de 2013, portanto, demonstrava ser tanto um gesto de solidariedade ao "caso Manoel Mattos" quanto um instante de sua própria luta, de sua militância por direitos, sobretudo de crianças e adolescentes. Ao menos era o que eu, preocupado com o trabalho de campo de minha pesquisa de doutorado e anotando naquele caderno tudo o que conseguia colher daquilo que os participantes do seminário diziam, conseguia intuir da presença de Rosa. Assim que o seminário terminou, Rosa veio falar comigo. Deu-me um abraço e eu, feliz em vê-la, perguntei-a sobre a luta, sobre como andavam a sua inserção no Programa $e$ as ameaças que costumava sofrer. Mais de seis anos antes, Rosa ingressara no Programa de Proteção aos Defensores de Direitos Humanos em Pernambuco por conta de suas denúncias - e das consequentes ameaças - a respeito das ações de um grupo de extermínio. Rosa então me contou da morte de Gabriel, seu filho. Disse que agora

3 Manoel Mattos foi convidado pela Comissão Parlamentar de Inquérito do Extermínio no Nordeste para se pronunciar sobre os grupos de extermínio que agiam nas regiões de fronteira entre Pernambuco e Paraíba. O pronunciamento de Manoel ocorreu em 28 de outubro de 2003. À época, ele presidia a Câmara de Vereadores de Itambé. As declarações de Manoel à comissão constam no relatório final dos trabalhos da CPI. Esse documento é o que subsidia as informações por mim prestadas. 
pertencia ao Movimento Mães Pela Igualdade. De início, não compreendi. Eu já havia ouvido falar da presença dessa nova organização no Recife, mas não sabia que Rosa - com suas denúncias sobre justiceiros e grupos de extermínio - representavaa. "Mas como foi isso, Rosa?", "Eles mataram Gabriel, Roberto. E ele era homossexual". Entrevistei Rosa dez dias depois.

As narrativas de Rosa sobre sua trajetória de lutas e, especialmente, sobre o assassinato de Gabriel, seu filho, atravessaram minha tese de doutorado, orientada por Regina Facchini e defendida em março de 2017 junto ao Programa de Pós-Graduação em Ciências Sociais da Universidade Estadual de Campinas. Iniciada a partir de um "dado" presente no relatório final da Comissão Parlamentar de Inquérito do Extermínio do Nordeste - o curioso "dado" segundo o qual os grupos denunciados por Manoel Mattos exterminavam adolescentes $e$ jovens em conflito com a lei, supostos "marginais", trabalhadores rurais, sem-terras e homossexuais -, a pesquisa objetivou analisar narrativas sobre violência mobilizadas, notadamente, por militantes de movimentos sociais em meio a conflitos de classe, gênero, sexualidade e territoriais. Durante o percurso do trabalho de campo que propiciou a tese, entretanto, um grupo de personagens me assombrou persistentemente: os sujeitos acusados pela execução da violência, os "Eles" que mataram Gabriel.

Embora eu tenha privilegiado, no desenvolvimento das análises, as narrativas de meus interlocutores de pesquisa sobre as "vítimas" $e$ as disputas travadas em torno de sua legitimação, os homens acusados - sim, na imensa maioria das vezes, os acusados são homens - permaneceram como uma dúvida, algo mal resolvido em minhas análises, mas igualmente em meus dilemas teóricos e políticos. É que sua proximidade com as "vítimas", com as relações sociais por elas perfeitas, sobretudo com suas experiências de gênero, classe e racialização, levou-me muitas vezes a questionamentos acerca dos enfrentamentos diante 
dos quais as narrativas sobre violência são reivindicadas, mas principalmente acerca dos sujeitos que ocupam o lugar de "adversários" nesses enfrentamentos.

Mais diretamente, sem maiores cuidados de distinção teórica: eu me perguntei se, nesses conflitos, nós, militantes e pesquisadores também implicados naquelas disputas, não estávamos punindo nós mesmos ou, mais perversamente, aqueles sujeitos com os quais nos comprometemos em suas (e nossas) lutas por direitos. Tal questionamento provavelmente se deve ao fato de eu, não raras vezes, haver me deparado com acusados, réus ou indiciados estética e socialmente aproximáveis das vítimas cujas mortes os militantes e movimentos sociais pranteavam. No fim, tratavam-se quase sempre de homens jovens negros, ou racializáveis, pertencentes aos setores mais precarizados da classe trabalhadora, as vítimas mais óbvias do que se vem chamando de "guerra às drogas", de "encarceramento em massa" e de "extermínio da juventude negra". No fim, "Eles" se achavam próximos demais de Gabriel na configuração, inclusive estatística, do que costumamos entender como sendo os alvos prioritários da violência e da criminalização.

Em outras palavras, no percurso do trabalho etnográfico, meu contato com as narrativas sobre violência acionadas por militantes de movimentos sociais, disputadas no interior dos autos de inquéritos policiais e processos judiciais ou em sessões do tribunal do júri, apontava para a conclusão perturbadora de que os sujeitos acusados pela execução da violência $e$ as próprias vítimas de violência experienciam relações sociais compartilhadas. Enfim, é sobre essas "proximidades" que pretendo tratar neste artigo. Aqui, considerando parte das narrativas sobre violência que compuseram o corpus de minha pesquisa doutoral, eu objetivo perseguir analiticamente as relações sociais compartilhadas entre Gabriel e "Eles", a vítima e seus algozes. Aquilo que os aproxima. Também procuro, todavia, compreender aquilo que, conforme aquelas narrativas, distancia-os: centralmente, o que meus interlocutores designam como "violência". Dá-se que, apesar de toda essa assombrosa proximidade, "Eles" continuam sendo 
"Eles", aqueles que mataram, contra Gabriel, que permanece sendo aquele que morreu.

Para tanto, este texto se estrutura a partir de dois diferentes momentos etnográficos vivenciados durante o trabalho de campo. $\mathrm{O}$ primeiro desses momentos advém das narrativas tecidas por Rosa durante a entrevista que ela me concedeu, no apartamento onde morava sob sigilo, no centro do Recife, na tarde do sábado, 23 de novembro de 2013. O segundo momento, por sua vez, deriva das narrativas produzidas durante a sessão do tribunal do júri acerca do homicídio de Gabriel, ocorrida em 17 de junho de 2015, num dos auditórios do Fórum Thomaz de Aquino, também localizado no centro da capital pernambucana. Acredito que a exploração analítica desses dois momentos etnográficos permitirá a percepção das tensões entre tais aproximações $e$ distanciamentos nos interstícios narrativos da conflituosa caracterização de algozes e vítimas. Essa exploração se desenvolverá, no entanto, tendo como ponto de partida duas questões fundamentais: a) o que venho chamando de "reciprocidades constitutivas" entre as relações sociais; $e$ b) a participação dos sujeitos, de suas experiências e relações nos processos de Estado, nas formas de produção de Estado.

Como tento indicar no transcurso deste texto, a questão das reciprocidades constitutivas remete ao argumento de que as narrativas sobre a morte de Gabriel, o menino de Rosa, são urdidas em relações de gênero e de sexualidade - daí a gravidade narrativa do "e ele era homossexual" e o esforço de definição de sua morte como homofóbica -, mas também em relações territoriais, de classe, racialização, geração etc. que perfazem seja quem as narra, seja a vítima e até mesmo aqueles que ocupariam a posição de algozes, os "Eles" que assassinaram Gabriel. Essas relações sociais se fazem umas através das outras e, como se verá, oportunizam, por exemplo, que Gabriel e "Eles" atravessem experiências geracionais, de classe e racialização suficientemente afins para que Gabriel e "Eles" consistam no modelo, na personagem típica daqueles alvos prioritários da violência e da criminalização. 
A arquitetura desse argumento é herdeira evidente dos avanços feministas e dos estudos de gênero e sexualidade acerca das "interseccionalidades" (Piscitelli, 2008; Facchini, 2009; 2008; França, 2012; Moutinho, 2014) e das "consubstancialidades" (Kergoat, 2010; Hirata, 2014). No melhor desses dois campos compreensivos - que, há de se notar, dissentem um do outro $e$ não são sequer internamente homogêneos - são os entrecruzamentos $e$ as reciprocidades constitutivas entre as relações sociais o que permanece em relevo. Dessa forma, essas relações não se somam, substituem ou alternam. Nas palavras de Anne McClintock (2010:19), raça, gênero e classe, por exemplo, "existem entre si e através dessa relação - ainda que de modo contraditório e conflituoso". Já para Danièle Kergoat (2010:94), as relações "formam um nó que não pode ser desatado no nível das práticas sociais, mas apenas na perspectiva da análise sociológica". No que me interessa desses dois campos e dos entrecruzamentos por eles delineados, a sua valorização da "experiência" ou da "experiência histórica" é o que salta.

Como nota Avtar Brah (2006), a experiência é um conceitochave no feminismo desde a assunção da palavra de ordem segundo a qual "o pessoal é político" $e$ os grupos de conscientização ofereceram a ocasião para que as experiências diárias, individuais e coletivas das mulheres fossem palavreadas $e$ compartilhadas. Mas essa experiência - Brah (2006:360) se faz categórica quanto a isso - não deve ser imaginada como o predicado posterior a um sujeito prévia e plenamente concebido. Ao revés, ela, a experiência, é "o lugar de formação do sujeito". Tomar as reciprocidades como experiências requer a apreensão das próprias categorias analíticas como conflituosas e móveis. Ao falar em gênero, desse modo, está-se necessariamente a dizer de processos de generificação ou, no vocabulário de Judith Butler (2010b), de performatividade de gênero. "Feminino" $e$ "masculino", para além de "construtos culturais", são categorias móveis e maleáveis que se atualizam nas práticas dos sujeitos como norma e/ou transgressão e não se conformam em díades de opostos. Antes, são femininizações e masculinizações 
historicamente contextuais, individuais e coletivas, acionadas segundo os confrontos e as acomodações próprios a determinadas relações de poder. Analogamente, como aponta McClintock (2010), "raça" não passa de um instante aparente de processos profundos de racialização. E sexualidade remete não aos contornos de um sexo pré-cultural ou pré-discursivo, mas a "roteiros sexuais" manipuláveis e flexíveis, como quis John Gagnon (2006), ou a um "dispositivo" implicado em "saber", "poder" e "subjetivação", como definiu Michel Foucault (2010).

A seu tempo, a segunda questão que serve de ponto de partida analítico para este artigo concerne à apreensão dos modos como sujeitos, suas experiências e relações atuam nos processos de produção de Estado e, reciprocamente, como esses processos participam da compleição daqueles sujeitos $e$, logo, de suas experiências e relações. A apreensão desses modos de produção de Estado impede a tomada do "Estado" como uma estrutura apriorística, homogênea e monolítica e implica na complexificação disso que costumeiramente nomeamos como "Estado", permitindo que lancemos luz sobre as práticas e os conflitos, estejamos tratando do "Estado-sistema" ou mesmo do "Estadoideia", se nos valemos dos conceitos empregados por Philip Abrams (1988). Considerando a noção de "Estado-sistema", por exemplo, far-se-ia necessário prestar atenção tanto nos procedimentos burocráticos mais ordinários que assentam vítimas $e$ algozes em posições diametralmente apartadas nas páginas da denúncia timbradas pelo servidor do Ministério Público ou nas disposições das cadeiras e mesas em uma sala do tribunal do júri, quanto nos sujeitos que agem sobre esses procedimentos.

Esses sujeitos são o servidor público ligado ao Sistema de Justiça, o juiz, o promotor de justiça, mas, também, aqueles que se mobilizam politicamente para que o "processo ande" $e$ "a justiça seja feita", e mesmo aqueles que se debruçam analiticamente sobre um "caso", tornando-o objeto público de reflexão acadêmica. Nesses termos, Rosa, militantes de movimentos sociais e, igualmente, eu próprio participamos dos processos de produção de Estado. Em suas narrativas sobre sua 
trajetória de vida, Rosa participa intensamente das mobilizações pela promulgação do Estatuto da Criança e do Adolescente, articula a Rede de Combate ao Abuso e à Exploração de Crianças e Adolescentes, preside o Conselho Estadual da Criança e do Adolescente e, quando ameaçada pelos integrantes do grupo de extermínio, acaba ingressando no Programa de Proteção aos Defensores de Direitos Humanos. Nos postos que ela ocupou, mas sobretudo em suas lutas por direitos, inclusive em sua luta pela definição do assassinato de Gabriel como homofóbico e pela punição dos culpados, Rosa compõe processos de Estado. Ela se dedica ao "fazer Estado", disputando projetos de Estado, a necessidade de políticas públicas, por exemplo, e respondendo aos requisitos característicos às lógicas estatais. Assim, Rosa se faz "sujeito" ao passo em que, citando Sílvia Aguião (2014), "faz(-se) (no) 'Estado"”.

Entretanto, como tentarei indicar nas próximas páginas, além de Rosa, dos demais militantes dos movimentos sociais e de mim, "Eles" - que mataram Gabriel - também participam desses processos de produção de Estado. Isto, não só porque "Eles" desempenham a imagem do algoz e, assim, antagonizam-se à imagem da vítima, ocupando previsivelmente a díade de opostos $e$ algumas daquelas cadeiras da sala do tribunal do júri - cadeiras normalmente ocupadas por pessoas que compartilham, com "Eles", experiências de classe, geração, racialização etc., como compartilharia Gabriel -, mas inclusive porque cabe a "Eles" a encarnação da ideia de "crime". "Eles" oferecem a carne e o corpo que se forjam pela criminalização, uma dimensão inexorável dos processos de Estado como os conhecemos.

De acordo com Abrams (1988), parte dos processos de produção de Estado está na ideia de Estado como um "ente", ou seja, na "ficção" - profunda e cotidianamente "real" - de que "o Estado" consiste num sujeito a priori. Seguindo as pistas deixadas por esse autor, creio ser possível argumentar que a ideia jurídica do "crime" como forma abstrata, exercível por um sujeito abstrato que, de acordo com os manuais de Direito Penal, realiza o "fato típico, antijurídico e culpável", dimensiona substancialmente 
aquele "Estado-ideia". A noção jurídica de crime informa a "ideia de Estado". Mas de tal maneira que, ao menos em narrativas oficiais, como aquelas dos manuais jurídicos com que precisei me defrontar durante os meus anos como estudante do curso de direito, é em reação ao "crime" que "o Estado" justifica e mobiliza a ideia de "monopólio da violência". Essa "violência", contudo, tida como "legítima" em narrativas oficiais de composição "do Estado", confronta a "violência" que separa algozes de vítimas, "Eles" de Gabriel, nas narrativas de meus interlocutores de pesquisa - as quais, como notei, também participam dos processos de produção de Estado, ainda que marginalmente.

Naquelas narrativas oficiais, portanto, põe-se, de um lado, a ideia de "monopólio da violência", suposta "legítima", e, do outro lado, põe-se a "violência" inadmissível que, nas "formas estatais de inteligibilidade", deve ser lida como "crime", enquadrada num "tipo penal", para ser combativa por meio do acionamento do "monopólio da violência". Claro, nas lutas por direitos, nos conflitos sociais que perfazem os processos de Estado e são por eles perfeitos, mesmo nas disputas acerca do reconhecimento público da morte do menino de Rosa como um homicídio motivado por homofobia, como se verá, os termos dessa dicotomia - "violência legítima" x "violência ilegítima/crime" acham-se em xeque, eles mesmos sob conflito. De pronto porque a suposição de legitimidade se encontra sob contestação constante, mas inclusive porque a identificação entre "violência ilegítima" e "crime" não se sustenta sem ambiguidades.

Como este artigo suscita, as histórias de Rosa sobre Santana foram imprescindiveis para a minha compreensão das reciprocidades constitutivas entre as relações sociais $e$ das experiências dos sujeitos na vivência e no engendramento dessas reciprocidades. Assim como tais histórias, somadas às narrativas policiais e judiciais que atuaram na contextura da morte de 
Gabriel como um "caso de homofobia" 4 , acabaram se mostrando decisivas para que eu compreendesse o lugar do "crime" no interior das relações sociais conformadas pelas (e conformadoras das) narrativas sobre violência que se tornaram meu corpus de pesquisa. Acontece que, se de antemão, o "crime" exsurge narrativamente a partir da noção jurídica de crime, como um "outro" de que é preciso se diferenciar para garantir a imagem apreensível da "vítima", perscrutando as narrativas sobre violência mais de perto, transitando entre suas múltiplas camadas de conflitos e ambiguidades, o "crime" - ou o processo de criminalização - revela-se próximo, nada distante. O "outro" consiste num "exterior constitutivo", se me valho do léxico empregado por Butler (2002) e Foucault (2008).

Situado nas experiências dos sujeitos, o crime perde em abstração, corporifica-se nos "tipos" de sujeito criminalizáveis, nas relações de racialização, gênero, geração, classe etc. que eles experienciam, e, embora remeta inescapavelmente à noção jurídica de crime, não coincide com a experiência do que Rosa, por exemplo, classifica como "violência". Aqui, violência e crime não são sinônimos, de modo que "crime" não traduz "violência". "Eles mataram Gabriel", manobraram violência, portanto, incorreram naquilo que Rosa se esforça para provar ser inadmissível. Mas, antes, "Eles" também preencheram relações sociais - em várias dimensões permeadas pelo crime, pela prática de roubos, pelo comércio de drogas ilícitas e pelos processos de criminalização, os quais operam mesmo que o "fato típico" não tenha sido realizado - que conformavam a vizinhança do bairro de Santana, o cotidiano das crianças com que os filhos de Rosa brincavam, as batidas e abordagens policiais que, se classificadas como arbitrárias ou violadoras de direitos, levavam Rosa a denunciar as "violências de Estado" cometidas contra aqueles jovens, seus filhos ou não, mas todos eles, os meninos de Rosa.

\footnotetext{
4 Seguindo as análises desenvolvidas por Paula Lacerda (2012), estou atento para o fato de que "casos" assim, como o "caso Gabriel" ou o "caso Manuel Mattos", resultam de esforços e disputas para tecê-los.
} 


\section{2. "Antes eu tinha $5 \%$ de medo, hoje eu tenho $0 \%$ de medo": sobre Rosa.}

Rosa nasceu e se criou na Paraíba. Cedo, ainda na escola, em meados da década de 70 em João Pessoa, iniciou sua militância no movimento estudantil. Integrou o grêmio do colégio em que estudava $e$ integraria as fileiras do movimento estudantil da UFPB. Ela conta que sua dedicação ao movimento estudantil representava, de certo modo, uma resposta às posturas do pai. Policial militar, ele era um homem violento. "Tem muita coisa que meu pai fazia e que eu não gostava, por ser militar". Rosa diz que presenciou o pai agredir e arrastar pela orelha um vizinho que estava surrando a própria mulher. $\mathrm{O}$ homem sangrava nas mãos de seu pai. Noutra ocasião, seu pai "pegou" seu irmão. Ele voltava de uma atividade do movimento estudantil e o pai, contrariado com a inserção dos filhos no movimento, surrou-o com um cabo de aço e obrigou o filho a seguir, ajoelhado, do quintal até o quarto de Rosa, o quarto de outra irmã e o quarto da mãe para pedir sua benção, de joelhos. Outra vez, o pai encontrou Rosa na rua, em uma ação do movimento, e a prendeu no camburão da polícia. Trouxe-a, à força, para casa. Segundo Rosa, o pai trazia o quartel e o militarismo para dentro de casa. Assim como batia no filho, batia na esposa. "E a gente tinha que ficar calada porque era na época do regime militar e mulher e filho eram tudo calados, entendeu? E isso me indignava, eu era muito pequena e isso me indignava".

Por influência da mãe, católica e integrante da Pastoral da Criança até os dias de hoje, Rosa se aproximou da Igreja. Transitava pelos mesmos círculos paroquiais de Dom José Maria Pires, uma figura que, como Dom Helder Câmara em Pernambuco, foi fundamental para a expansão das pastorais $e$ comunidades eclesiais de base da Igreja Católica na Paraíba. Estimulada pelos pais aos estudos, Rosa concluiu um curso técnico em enfermagem e, depois, aos vinte e poucos anos, formou-se enfermeira pela UFPB. No início da faculdade, casou-se com um primo de Sapé - cidade onde se originaram as Ligas Camponesas 
na Paraiba - que havia sido seu primeiro namorado. A primeira pessoa da família a entrar em uma universidade, Rosa se dedicava aos cursos porque estava convencida de que precisava de autonomia. "Eu dizia que não queria ser submissa. (...) Eu dizia isso, eu sempre disse isso. Era uma coisa muito mais de feminismo mesmo, de militância. Eu dizia pra minha mãe: eu não quero passar o que a senhora passa". Com o fim da faculdade, Rosa trabalhou como enfermeira em alguns hospitais de João Pessoa. Mas isso duraria apenas alguns meses. Seu marido era caminhoneiro e em razão do trabalho dele, em 1983, Rosa, o marido e o primeiro filho do casal, um bebê com menos de um ano, mudaram-se para Recife. Passaram então a morar em Santana, um bairro periférico próximo à Ceasa. ${ }^{5}$

O marido de Rosa abriu uma "loja" - acho que uma banca de hortifrutigranjeiros - na Ceasa. Durante a semana, ele trabalhava com o caminhão e a loja era administrada por outras pessoas. Mas aos finais de semana, ele mesmo cuidava da loja "pra tomar conta, pra fazer os pagamentos, a chegada de mercadoria, essas coisas". Rosa começou a acompanhar o esposo nessas idas à Ceasa. Fazia a própria feira e esperava que ele resolvesse as pendências da loja. "Aí foi quando eu comecei a conhecer as meninas e a situação das meninas na Ceasa. Toda minha história aqui começou na Ceasa. E aí foi quando eu comecei a ver e a conversar com as meninas". As meninas, de que Rosa fala, eram crianças e adolescentes que transitavam na feira em busca de restos de comida e doações de fregueses e feirantes. À época, a Ceasa permanecia aberta ininterruptamente, de forma que o fluxo de caminhoneiros e comerciantes era intenso inclusive durante as madrugadas. "Muitos comerciantes, que muitas vezes ficavam lá pra tomar conta das lojas, das mercadorias, não vinham pra casa pra dormir e ficavam lá e transavam com as

${ }^{5}$ O Centro de Abastecimento e Logística de Pernambuco (CEASA/PE) consiste numa Organização Social vinculada à Secretária de Agricultura e Reforma Agrária de Pernambuco. É uma grande feira de produtos hortifrutigranjeiros localizada numa região periférica de Recife. Por se tratar de uma "feira", de regra o centro é chamado de "a Ceasa", como se a sigla fosse um substantivo feminino 
meninas". Conversando com essas meninas, Rosa iniciou seu contato com as histórias sobre exploração sexual e terminou sabendo do "Caminhão do Faustão".

O Caminhão do Faustão consistia numa espécie de promoção ou sorteio promovido pelo apresentador do programa televisivo de mesmo nome. Alguns dos homens que circulavam pela Ceasa decidiram sortear as meninas que por lá transitavam e intitular esse sorteio com o mesmo nome do sorteio realizado pelo apresentador. "Tinha um sorteio de meninas para fazer sexo num hotel ali, na Av. Recife. E aí, o que era que acontecia? Fazia o sorteio e se essa menina fosse virgem o valor era maior. E (o pagamento às meninas) nunca era dado em dinheiro, era em cesta básica ou em roupa. E aí tinha muita venda de meninas virgens nesse Caminhão do Faustão". Ouvindo essas histórias, Rosa conversou com o Padre Giácomo, também ligado às Comunidades Eclesiais de Base, e resolveu montar um grupo de jovens na paróquia de Santana. Mas Rosa não pretendia afetar somente os jovens da paróquia. Queria atingir e aproximar as meninas da Ceasa. "E aí a gente começou a fazer uma fábrica de picolé, uma fabrica de vassoura. E eu comecei a trazer as meninas da Ceasa, (...) as meninas de dentro da Ceasa em situação de exploração sexual".

A aproximação das meninas possibilitou a Rosa montar um "grupo cooperativo", em que elas falavam de suas experiências e trajetórias de vida e, inclusive, do que acontecia na Ceasa e no tal "Caminhão do Faustão". Mais confiantes em Rosa, as meninas começaram então a mostrar fotografias em que elas mesmas apareciam, algumas vezes acompanhadas pelos homens do "Caminhão". As fotos, entretanto, eram apenas apresentadas a Rosa, não entregues a ela. "Elas nunca me davam essas fotos porque diziam que se eu pegasse essas fotos quem ia morrer era eu. Elas sempre me alertavam dessas ameaças". Segundo Rosa, "no desespero", uma dessas meninas mostrou a ela uma fotografia de um "bacanal" dentro de um quarto de motel. Na foto, achavam-se meninas adolescentes e alguns homens cujos rostos não se podia ver. "Era sexo oral, sexo anal, de todo jeito". "Eles 
faziam e tiravam foto". Essa menina, contudo, contou a outras pessoas que havia mostrado a fotografia a Rosa. Não demorou. Coincidentemente ou não, foi assassinada sob o viaduto da Ceasa. Em pouquíssimo tempo, Rosa soube da morte. As meninas que participavam do grupo cooperativo correram à porta de sua casa e, "desesperadas", falaram do ocorrido. Rosa seguiu para o viaduto. "Eu fui lá pra ver a menina. A menina estava com a calcinha no meio do joelho e com uma pedra na cabeça". "Ela foi apedrejada, Rosa? Foi morta com uma pedra?". Sim. Rosa confirmou com a cabeça.

Quando da morte dessa primeira menina, a dedicação de Rosa ao grupo de jovens da Igreja e às suas denúncias desses casos de violência já a levavam, paulatinamente, a se envolver com outras organizações vinculadas às lutas por Direitos Humanos e, em especial, por direitos de crianças e adolescentes. "E, cada vez mais, eu fui me envolvendo por conta dessa violência, fui me envolvendo, me envolvendo... Ali, dentro da comunidade. E começaram a vir as mulheres, começaram a denunciar pra mim. E começaram a vir outras coisas, os meninos que eram presos...". Era final da década de 80 e Rosa se juntou ao Movimento PróCriança, à organização Justiça $e$ Paz e às movimentações políticas relacionadas ao Estatuto da Criança e do Adolescente, chegando a viajar para Brasília para participar das mobilizações pela aprovação do ECA. Em meio às suas atividades de militância, Rosa começou a atuar numa comunidade periférica, bastante próxima a Santana, chamada Guerra nas Estrelas. Lá, ela conheceu Marieta, uma importante liderança comunitária com quem passou a conviver. "A gente conheceu Marieta quando tudo era barraco de tábua ali. Guerra nas Estrelas era tudo tábua. Era invasão. Era um favelão. Não tinha saneamento, não tinha nada". Juntas, atuaram na "escola comunitária", montaram um grupo de mulheres e se aproximaram das freiras que também desenvolviam atividades na região.

Rosa, que se aproximava do Partido dos Trabalhadores, conta que Marieta, entretanto, aliou-se a personagens proeminentes de partidos políticos da direita, sendo "canalizada 
pra outro lado". As duas tomariam caminhos diversos em suas militâncias. Mas os enfrentamentos entre suas posições se extremariam com o crescimento de Victor, filho de Marieta, no "mundo do crime". Desde a constituição do grupo de jovens na paróquia do Padre Giácomo, em Santana, Rosa observava de perto as movimentações dos jovens no local. As meninas da Ceasa preenchiam suas preocupações iniciais. Porém, o incremento de um grupo de jovens justiceiros - Rosa também usa a expressão grupo de extermínio para designá-los - e o aumento de cenas de violência, de responsabilidade desse grupo, em Santana e em Guerra nas Estrelas, conduziram as atenções de Rosa para a implicação dos jovens com a violência. Segundo Rosa, Victor teria se aproveitado da prisão do líder desse primeiro grupo para conquistar a liderança dos demais rapazes. Ele contava, ademais, com a retaguarda dos laços políticos de Marieta. Ainda menor de idade, chegou a ser preso. Mas logo foi solto. "Por conta do envolvimento político da mãe. Ele foi preso quando era menor, a mãe ligava e mandava tirar, ele saia. E ele cresceu dessa forma. Ele nunca foi preso pra ficar preso. Ele sempre era solto. A mãe conseguia articular e ele era solto".

Victor e os demais rapazes, contudo, eram conhecidos de Rosa desde meninos. Vários deles chegaram a participar das atividades do grupo de jovens da paróquia. Um pouco mais velhos, batiam às portas das festas do salão paroquial armados. As festas se destinavam a recolher algum dinheiro para o financiamento do grupo da paróquia. Rosa não os impedia de entrar, mas pedia que eles lhe entregassem as armas. "Aí eu fazia pra eles: '- armado aqui você não entra'. E era uma mulher que dizia isso pra eles, com um monte de jovens, porque não tinha pessoas adultas, era com jovens". Eles entregavam as armas $e$ Rosa as devolvia ao final da festa. Mas pelas festas, também passava um delegado, "todo mundo tinha medo desse delegado". À época, as seguidas denúncias de violência que Rosa realizava já faziam dela conhecida da polícia. O tal delegado, temido, dizia que passava pela paróquia para proteger a festa e a própria Rosa. "Mas aí, depois, eu descobri que não. Porque ele ia lá pra pegar o 
dinheiro da droga dos meninos, porque os meninos vendiam drogas". Os meninos, que haviam passado pelo grupo de jovens $e$ se aglutinavam, com Victor, no grupo de extermínio de que fala Rosa, trabalhavam no mercado varejista de drogas ilícitas $e$ prestavam contas a policiais.

"Toda vida lá em Santana foi corrompido. Quando eu comecei a perceber que a polícia tava envolvida, muito envolvida ali dentro, eu comecei a me cuidar mais e a observar mais". Os próprios meninos enumeravam os sujeitos "de Estado" ligados ao mercado de drogas e que interviam, de algum modo, nos territórios de Santana e Guerra nas Estrelas. Eram policiais civis, militares, federais, integrantes da aeronáutica, políticos. Alguns deles ocupavam altos postos estatais. Victor, o filho de Marieta, era afilhado de um político graúdo. Seu batismo aconteceu na Igreja de Boa Viagem. ${ }^{6}$ "Tá danado, Rosa! Victor foi batizado na Igreja de Boa Viagem?". "Na Igreja de Boa Viagem". "Um menino de Guerra nas Estrelas?!". "Foi em Boa Viagem porque o político quis lá. Você entendeu agora em que seara eu tou envolvida? Porque além de ter polícia, tem político. Tinha o tráfico de droga, tinha a exploração sexual". Rosa, de início preocupada com os casos de exploração sexual, passa a saber, a partir do que as meninas lhe diziam, das festas a que elas eram levadas e em que conviviam com políticos, policiais e com os integrantes do grupo de extermínio.

À medida que Rosa desatava os nós das relações em que meninas, meninos e agentes tidos como "de Estado" se implicavam, as ameaças sobre ela cresciam. Tais ameaças se iniciaram com a consolidação dos trabalhos de Rosa na Ceasa, na década de 90. "Ligavam pra mim e diziam assim: 'olha, é melhor você deixar o que está fazendo na Ceasa. E sempre era de um orelhão de dentro da Ceasa". E aumentaram ao tempo em que as ações de Rosa surtiam efeito. Já nos anos 2000, por meio de

6 Rosa diz o nome do "político graúdo". Eu, contudo, preferi sequer disfarçar o tal nome. Boa Viagem, por sua vez, é um bairro praieiro e está entre os mais caros do Recife. 
contatos com movimentos sociais, uma produtora de um programa jornalístico de um canal de televisão decidiu entrar, com Rosa, na Ceasa e realizar uma matéria sobre os casos de exploração sexual de adolescentes. A matéria estava quase pronta, prestes a ir ao ar, quando Rosa e a produtora tiveram notícia de restrições à sua veiculação pelas altas esferas da emissora e do governo estadual. "Pra você ver que é tão sério que eles descobriram essa matéria e descobriram que a gente tinha dado flagrante da exploração sexual na Ceasa". A matéria foi ar. "Aí foi aquele rebu". Membros do governo estadual marcaram reunióes, convocaram Rosa e a Rede de Combate ao Abuso e à Exploração de Crianças e Adolescentes, que Rosa chegou a presidir, para realizar uma pesquisa na Ceasa sobre o modus operandi da exploração, mas implementaram uma política de controle sobre as meninas contrária às posições de Rosa. "Entrou com um camburão lá dentro e só quem sofreu foi as meninas. Jogaram várias meninas dentro do camburão. Recolhiam, tiravam $e$ botavam as meninas pra fora. Isso de madrugada. E nisso as meninas correm lá pra casa".

Conheci Rosa pouco tempo depois da veiculação dessa matéria. Eu estava no segundo ano do curso de Direito e pertencia ao Núcleo de Assessoria Jurídica Popular Direito nas Ruas (NAJUP), da Universidade Federal de Pernambuco (UFPE). Por conta das atividades do NAJUP, eu costumava frequentar as reuniões do Movimento Nacional de Direitos Humanos, o MNDH, em Recife. Rosa frequentava as mesmas reuniões. Atuava em uma organização não governamental de defesa de direitos de crianças $e$ adolescentes $e$, ao relatar as ameaças que continuava a sofrer, sempre apresentava denúncias sobre os Power Rangers. Àquele tempo, Victor, o filho de Marieta, havia aumentado seu potencial de capilarização no "mundo do crime" e o grupo liderado por ele em Santana ganhara nome de super-herói. Os Power Rangers agregavam dezenas de rapazes, massificavam sua atuação no mercado de drogas ilícitas e multiplicavam as cenas de violência que Rosa persistia denunciando. Mas, segundo Rosa, duas 
daquelas cenas a levariam ao limite: os assassinatos de Fernanda e Felipe.

Fernanda integrava o grupo de mulheres com que Rosa trabalhava na comunidade. Seu irmão foi morto por membros dos Power Rangers e Fernanda decidiu comparecer à delegacia de Santana para relatar a causa da morte e os nomes dos executores. "Quando ela chegou na delegacia, ligaram pra Victor na hora". Logo que Fernanda deixou a delegacia, contudo, foi apanhada por rapazes ligados aos Power Rangers. Eles a surram e ameaçam. Fernanda então voltou à delegacia. Entregou as identidades de quem a surrou. Dois dos Power Rangers foram presos pela polícia. Um deles "colaborou com a polícia e entregou o resto do grupo". Fernanda saiu novamente da delegacia em direção à casa onde vivia com os pais e os filhos. Victor e mais dois rapazes, no entanto, também seguiram para a casa de Fernanda. Encontraram-na em casa. Mataram-na com 12 tiros. "Foi aquela morte brutal, que foi com doze tiros na frente do pai, da mãe $e$ dos filhos". Assim que Fernanda morreu, as meninas ligaram para Rosa. Ela saiu do trabalho e voltou para Santana. "Eu vou correndo, quando eu vou chegando perto da casa dela, eles vão passando na minha frente com o carro". Rosa viu Victor passar.

Felipe, por sua vez, morreu na frente da casa de Rosa. Ela conta que alguns dos Power Rangers procuravam um rapaz chamado Anibal. Porco, um integrante do grupo, apontou Felipe como sendo Anibal. Fazia dez minutos que Rosa havia chegado do trabalho. "Eles vieram com o menino, passaram na frente da escola, toda comunidade viu. Trouxeram o menino e quando chegou na frente da minha casa deram uma rasteira no menino, deram um tiro nas costas e dois tiros na cabeça". O corpo perfurado de Felipe permaneceu entre a calçada e a rua até que duas policiais, conhecidas de Rosa, chegaram ao local. "Rosa, tu sabe?". "Sei não. Eu não vi nada". Rosa havia visto. Não disse o que sabia. "Porque eu tava tão tensa, tão nervosa e revoltada ao mesmo tempo. E eu não podia falar porque eles estavam... Tem um pé de árvore na frente da minha casa e eles estavam em pé, eu vi eles lá em pé, e eu ia dizer alguma coisa?". Não poderia 
dizer. Não disse. Porco, entretanto, o rapaz que apontou Felipe como sendo Anibal, seria um dos assassinos de Gabriel, o filho de Rosa, em 2010. O corpo de Felipe restava defronte à casa de Rosa enquanto Porco e outro rapaz conversavam do outro lado da rua. "Rapaz, vamo chamar a mãe dele?". "Não, deixe a mãe dele dormindo. Ele tá num sono tranquilo, um sono eterno". "O Porco dizia isso. E eu não sabia que ele ia ser o assassino do meu filho. $\mathrm{E}$ ele debochava do menino".

[Mas a morte desse rapaz foi o estopim para você, Rosa?] Foi. Foi quando eu disse: " - não dá mais pra ficar calada. Não dá mais pra ficar quieta". A morte dele e a morte de Fernanda. Na de Fernanda, eu já era Presidente do Conselho Estadual da Criança e do Adolescente. E aí não dá mais pra ficar quieta. E Marineide era vice-presidente comigo. Marineide veio conversar comigo. Eu disse: "Marineide, é muito sério ali, se vocês quiserem fazer alguma coisa, vocês vão ter que fazer". E eu não podia fazer nada porque a minha casa era aqui e na outra rua eles tinham alugado um duplex. E esse duplex dava pra ver de cima, dava pra ver a minha casa. Eu via eles limpando arma lá, eu via eles fumando maconha e eles viam a minha casa, era estratégico. Eu ali já começava a ser cercada por eles. Começava a ser cercada mesmo. Aí começou a fazer todo trabalho e logo após eles começaram a ser presos. ${ }^{7}$

Em meio ao aumento de ameaças e denúncias, a visibilidade sobre Rosa também aumentava. Ela galgava posições significativas em meio às organizações de defesa de Direitos Humanos. Tornava-se mais e mais reconhecida por sua luta e, com a majoração dos perigos por ela atravessados, ingressou no Programa (governamental) de Proteção aos Defensores de Direitos Humanos. Passou a ser uma "Defensora" protegida. Quanto mais suas denúncias se difundiam, mais seu nome se espraiava e os

\footnotetext{
7 Esta e as duas próximas falas de Rosa destacadas do corpo do texto resultam da entrevista em profundidade realizada com ela, como dito, em 23 de novembro de 2013
} 
custos da efetivação das ameaças contra a sua vida se multiplicavam. "Porque se eles tirassem a minha vida, hoje eu faço essa leitura, (...) ia ter uma repercussão muito maior". "Pra conseguir isso, tiveram que tirar a vida do meu filho". Nas interpretações de Rosa, portanto, a morte de Gabriel se deveu ao jogo de ameaças contra ela e sua militância. Mas essa é apenas uma das razões. A outra seria a homofobia.

De acordo com o que Rosa soube das investigações policiais, os dois executores premeditaram o assassinato de seu filho. Primeiro, embebedaram um timbu - uma espécie de gambá de orelhas brancas - capturaram o animal, mataram-no $e$ arrancaram o seu rabo para, com ele, surrar Gabriel. "Isso pra cortar Gabriel todinho". Depois, prenderam o rapaz. Espancaramno. "É muito interessante, veja só, que a história é que não era pra matar Gabriel, era pra dar um susto. Susto em quem? Pra quê? Eles não dizem isso". Mataram-no durante o espancamento. Chutes em sua cabeça provocaram um grave traumatismo craniano. "Tiraram Gabriel do local, levaram Gabriel pra um lugar que eles dizem de pegação, que é de exploração sexual, $e$ maquiaram". Gabriel morava com Rosa, tinha 24 anos. Desapareceu na quinta. Rosa só conseguiu encontrá-lo no sábado à noite, quando o filho já se achava num hospital de Recife. "Ele estava intubado, em coma induzido". Gabriel faleceu no domingo pela manhã. Sua morte, contudo, inaugurou uma nova trincheira de luta para Rosa. As investigações promovidas pela primeira delegada a assumir o caso concluíram que Gabriel morreu por estar em um "lugar de pegação" $e$ por ser "indiretamente envolvido com drogas".

Teve um primeiro momento, em que a delegada fez a fala homofóbica. Ela me escuta, faz a ouvida. Três horas da tarde, eu saio de lá da delegacia e quando é as quatro horas, ela dá uma entrevista pra um jornal. ${ }^{8}$ Porque teve

8 Rosa menciona o nome do jornal e o nome do canal de televisão que veiculou as matérias sobre a morte de seu filho. Preferi, todavia, evitar maiores explicitações. 
uma repercussão muito grande e a televisão fez várias matérias, de manhã, de tarde e de noite comigo, falando da morte de Gabriel. E aí esse jornal foi lá ouvir a delegada. E aí a delegada quando ela diz: "- ele tem um envolvimento, ele está envolvido indiretamente com droga", ou você tá, ou você não tá. [Envolvido indiretamente com droga]. Isso, entendeu? Foi a fala dela. E está na exploração sexual. E já foi dando, dizendo que não tinha. E aí eu conhecendo o filho que eu tinha, jamais eu poderia ficar calada. E aí Breno ligou pra mim, Isaac e Guilherme?: "- Rosa, venha aqui na sede da organização que a gente precisa conversar com você”. Aí eu fui. (...) Aí quando eu cheguei lá, Guilherme disse: "- você viu a matéria?". Eu disse que vi. "- Você quer fazer, dar uma coletiva de imprensa? Pra gente chamar a imprensa aqui, a gente chama pra amanhã, pra você defender o seu filho?". Eu disse, quero. Eu estava pensando como é que eu ia fazer. E aí veio Carolina, do Conselho Estadual de Direitos Humanos, veio Mariazinha, do Programa de Proteção aos Defensores, veio todo mundo. Foi quando eu coloco que meu filho era gay, sim. Agora não precisa ficar gritando pelos quatro cantos dizendo que meu filho era gay. E meu filho era amado. Meu filho não tava envolvido com droga, porque eu conhecia Gabriel, ele não tava envolvido com droga. [Nem com exploração]. Nem com exploração. Até porque eu conhecia também. Gabriel saía pra casa dos amigos. Gabriel não dormia fora. (...) Porque se fosse um menino que tivesse esse vício de dormir fora de casa eu também não tinha nem me importado. Porque se ele dorme em casa, vai chegar.

Rosa passou então a dedicar esforços para a legitimação da vítima, seu filho. Ela precisava afastar de Gabriel os estigmas a ele associados pela primeira delegada. "Essa delegada pensou que eu era uma pessoa que não tinha informação, como outras mães. (...)

9 Breno, Isaac, Guilherme, Carolina e Mariazinha são militantes ligados a organizações de Direitos Humanos e/ou ao Partido dos Trabalhadores. Rosa se refere a eles sem apresentações porque sabe que eu os conheço. 
Essas mães não são tratadas pelo Estado. Não são cuidadas pelo Estado. Eu cheguei lá e eu tinha informação, eu já sabia o que era Direitos Humanos, eu já sabia o que era a legislação". De fato, Rosa possuía bem mais do que "informação". Ela acumulava uma trajetória de lutas e, portanto, de articulações políticas que a subsidiariam naquele momento. A coletiva de imprensa e toda a pressão exercida pelos militantes e organizações de Direitos Humanos próximos a Rosa geraram efeitos. A Secretaria de Defesa Social dispensou a delegada inicial e, depois de uma semana, alocou uma segunda delegada para reiniciar as investigações. Essa segunda delegada conduziria as investigações a ponto de descobrir as premeditações para a morte de Gabrieldo timbu ao susto aparentemente desarrazoado - $e$ as alegações homofóbicas para o crime.

São duas motivações. Uma das motivações é a questão da homofobia, que eles usaram como homofóbicos, eles trazem falas homofóbicas, no depoimento deles. [O que eles dizem, por exemplo?] Eles dizem que Gabriel transou com eles e que saiu falando deles. E que eles eram homens e que nunca iriam sair com um gay. (...) Que eles eram homens que gostavam de mulher e não iam sair com gay. $\mathrm{E}$ tem outras falas que eu não lembro muito, que é muito grande. Tem outras falas. Eu lembro muito mais dessa que eu fiquei irritada. Disse que Gabriel tava com AIDS, que era gay e tava com AIDS e isso não é verdade. Então tem aquelas falas que são inverídicas. [O primeiro motivo era a homofobia]. A homofobia. E o segundo motivo pelo meu trabalho com a questão de Direitos Humanos.

Do que Rosa recorda das atas dos interrogatórios dos dois réus, Porco e o outro haveriam justificado suas atitudes em razão do que Gabriel falara sobre eles. "Eles dizem que Gabriel transou com eles e que saiu falando deles". Teriam argumentado também que Gabriel "era gay e estava com AIDS". Rosa classifica essas justificações como homofóbicas, valendo-se de um vocabulário típico ao Movimento LGBT. Logo depois do assassinato de 
Gabriel, Rosa conheceu uma organização norte-americana disposta a apoiar, no Brasil, uma organização de mães de LGBT vítimas de violência. Rosa foi indicada ao representante brasileiro daquela organização. "E, aí, ele manda pra mim um e-mail dizendo que estava procurando mães de homossexuais, e mães aguerridas, que não tivessem vergonha de botar a cara e dizer 'meu filho é gay e eu tou aqui defendendo meu filho', mães ativistas". Rosa aceita o convite e, ao lado de outras duas mães, funda em Pernambuco o Movimento Mães Pela Igualdade, através do qual ela aglutina mães e acompanha casos de violência contra LGBT, como o do seu próprio filho. "Acho que hoje eles se arrependem de não ter tirado a minha vida, porque veio uma força muito maior, muito maior do que a que eu tinha. Antes eu tinha $5 \%$ de medo, hoje eu tenho $0 \%$ de medo".

\section{3. "São cínicos, são debochados": sobre Galo e Porco}

[Nota do diário de campo; manhã de 17 de junho de 2015]. Fórum Thomaz de Aquino, bairro de Santo Antônio, centro do Recife. Avistei Rosa assim que cheguei ao auditório. Achava-se cercada por repórteres e câmeras de televisão. Concedia entrevistas, cumprimentava pessoas conhecidas, conversava com os advogados que serviriam de assistência à acusação, recebia integrantes de organizações de Direitos Humanos e militantes de movimentos sociais. Estava apreensiva. Havia quase cinco anos da morte de Gabriel. Agora, depois de tanto, Porco e Galo seriam levados a júri popular em razão do homicídio de que eram acusados. A sessão não demorou a começar. Após a abertura dos trabalhos pelo juiz, o sorteio dos jurados, a leitura da denúncia $e$ os interrogatórios dos réus, o Promotor de Justiça iniciou os debates pela acusação. Sua fala apresentou, de pronto, declarações iniciais prestadas por Galo junto à delegacia de polícia. Segundo as folhas do inquérito que o promotor lia diante da plateia e dos jurados, Galo contou, na delegacia, do rabo do timbu preparado para a surra no filho de Rosa. Falou da raiva que sentiu ao ouvir dizer que Gabriel teria espalhado haver transado 
com ele, com Porco e com outros de seus amigos. Afirmou, ainda, que o próprio Porco assumiu, no presídio onde ambos já se encontravam presos por conta de roubos, a autoria do homicídio. Lido o depoimento inicial de Galo, o promotor passou então a explorar outros testemunhos e declarações. Pretendia demonstrar que as declarações inicialmente prestadas por Galo na delegacia, $e$ posteriormente negadas por ele mesmo, faziam sentido. Trouxe, assim, ao auditório, as declarações de Matheus, um dos irmãos de Gabriel. "Que, certo dia, não lembra quando foi, Galo mostrou um animal, um timbu morto, o qual carregava nas mãos, e disse que era para dar uma surra em Gabriel, tendo o declarante dito que se fosse para dar uma surra em Gabriel, o declarante também se envolveria na briga". Em sua declaração perante a polícia, Matheus confirmou parte do que Galo contara. Haveria, de fato, uma "rixa" entre seu irmão e os rapazes porque, segundo disseram, Gabriel "estava espalhando que havia tido relacionamento sexual com eles". De acordo com Matheus, Gabriel sabia que Galo e Porco queriam surrá-lo. Após trazer a público as declarações de Matheus, o promotor se deteve sobre as controversas declarações de um detento chamado Jonildo. De antemão, Jonildo disse pouco. Falou que conhecia Gabriel do bairro de Santana, que Gabriel "era travesti e uma pessoa muito tranquila, não se envolvia em brigas". Ao ser perguntado, no entanto, como soube da morte de Gabriel, se ouviu algo dito por Galo ou Porco, Jonildo explicou haver sabido do assassinato somente através de um programa de televisão a que assistira no presídio. Não conversara com Porco ou Galo sobre o assunto, portanto. Foi o que disse. Desdisse, porém. No plenário, o promotor de justiça apresentou uma segunda declaração de Jonildo em que o rapaz retificava a sua primeira declaração: "que quando estava preso no Presídio Aníbal Bruno soube que Porco e Galo eram suspeitos de ter cometido o homicídio de Gabriel; que todos dentro do presídio também comentavam que os dois eram suspeitos de ter cometido esse crime; que inclusive sua genitora também, em uma das visitas, lhe contou que eles eram suspeitos". Jonildo modificou a versão inicialmente apresentada. Ao que disse 
na segunda oportunidade, ele parece não haver se contentado em apenas saber das suspeitas de que os dois Power Rangers haviam assassinado o filho de Rosa. Assim que Porco e Galo chegaram ao Presídio Aníbal Bruno, Jonildo resolveu perguntar diretamente aos dois se eles haviam matado Gabriel. "O declarante foi até eles e perguntou se foram eles que mataram Gabriel, tendo Porco e Galo dado sorrisos com ar de deboche". Esta última frase, o promotor leu em voz alta para, depois, dirigir-se aos dois réus que participavam da sessão e assistiam à sua acusação. "Não sei do que eles estão achando graça ali, agora. Não sei onde pensam que estão. Ninguém está contando brincadeira aqui. Eles não conseguem, é uma graça para eles. O outro parece que está em casa, assistindo à televisão". O promotor seguiu, então, à anunciação do testemunho de mais um rapaz. Flávio, segundo contou em audiência, residia em Santana e trabalhava descarregando caminhões na Ceasa. No bairro em que moravam, ele conheceu Gabriel, "uma ótima pessoa, muito amigo, legal e tranquilo". Quando Galo e Porco chegaram ao Aníbal Bruno, Flávio também se achava lá, preso, acusado de tráfico de drogas "injustamente". Na prisão, ouviu Galo assumir o assassinato de Gabriel. Antes, contudo, Galo reconhecera a surra. Flávio "(...) estava perto de outros presos quando ouviu Galo dizer para todos que ali estavam que havia dado uma pisa, batido em Gabriel a pauladas; que falou que foi ele, Galo e Porco, que bateu nele a pauladas". Em plenário, o promotor enfatizou a reação de Flávio ao que ouviu de Galo. O rapaz sentiu raiva, gostava de Gabriel, passou duas noites calado sem falar com ninguém. $\mathrm{O}$ promotor voltou, assim, ao testemunho crucial de Flávio: "ouviu no presídio Galo dizer que havia matado Gabriel a pauladas, juntamente com Porco". Após a descrição dos testemunhos de Jonildo e Flávio, o promotor mencionou ainda os testemunhos de mais um rapaz, igualmente preso, e de uma moça. Ambos alegaram, de modo vago, haver ouvido dizer algo parecido com aquilo que Jonildo e Flávio declararam e o promotor expôs anteriormente. Em suma, Galo e Porco eram culpados. Em meio à exposição de um e de outro testemunho, entretanto, o promotor pediu ao juiz que 
chamasse os dois réus ao comportamento. Ressaltava, mais uma vez, desse modo, a postura deles de "deboche". "Não são apenas debochados, são debochados porque são assim, perigosos". Nos argumentos levantados pelo promotor de justiça, o "deboche" de que ele acusava Galo e Porco durante a sessão do tribunal do júri, o "deboche" com o qual, segundo as declarações de Jonildo, eles teriam se referido à morte de Gabriel na prisão, indicava o desrespeito pelo ambiente, mas sobretudo o desrespeito pela questão sob discussão, a "vida". Tal desrespeito denunciaria a sua periculosidade. Mas essa periculosidade não seria maior do que a figura de Rosa. O promotor trouxe então à plateia uma passagem do depoimento de Porco em que Rosa é citada. Quando o questionaram sobre o porque de ele ser acusado de haver matado Gabriel, Porco respondeu: "A mãe dele era uma pessoa que procurava ajudar a gente. Ela me botou num curso, fez coisa que só a poxa por mim. De repente, ela virou a cabeça. Eu acho que é porque eu que induzi o outro filho dela a roubar comigo, né? Aí ela ficou com raiva de mim". Seguindo o depoimento de Porco, o promotor passou a explicar aos jurados que Rosa, apontada numa das cadeiras da plateia, era alguém que "ajudava". Sendo assim, mesmo com medo, as testemunhas então mencionadas teriam resolvido dizer o que sabiam sobre o assassinato do seu filho. Queriam também ajudá-la. "Mesmo com a periculosidade desses senhores (apontou para Porco e Galo), as pessoas que falaram eram pessoas que conheciam o trabalho de Rosa na comunidade. Daí o Jonildo dizer, como disse, que não falou pela primeira vez por medo". Nas palavras do promotor perante os jurados, estabeleceu-se uma dicotomia. De um lado, a mãe que ajudava a comunidade e que, no passado, tinha ajudado inclusive os que hoje são acusados pelo homicídio de seu filho. De outro lado, "dois acusados, pessoas indiscutivelmente voltadas para o crime", que conheciam Rosa desde meninos, que cresceram e se criaram às voltas de Gabriel e de seus irmãos, mas que, a despeito disso, possuíam "total desprezo pela vítima". "São cínicos, são debochados". Os réus estavam caracterizados, portanto. "Não se trata de condenar por antecedentes. Se trata de demonstrar quem 
são". "É preciso mostrar quem são". Ao promotor faltava ainda, entretanto, explicitar a razão da morte, sua causa. Moveu-se, assim, nesse sentido. "A vítima homossexual. E repito: se a vítima fosse uma mulher e tivesse dito que teve relação sexual com eles, a vítima não teria sido morta. Esta é a verdade. Sejamos realistas e botemos os pés no chão. Morreu porque era homossexual. Estamos sim com um crime típico de homofobia". Sendo a "homofobia" a causa do assassinato, o promotor relembrou o modo da morte, os chutes e as pancadas desferidos sobre a cabeça de Gabriel e que provocaram o traumatismo craniano. "O meio cruel, não há o que se discutir. Bem observado o que fizeram com a cabeça da vítima". Nas palavras do promotor, a crueldade e a brutalidade se comprovavam. Mas uma ressalva pareceu precisar ser feita. $\mathrm{O}$ promotor deixou claro que não pretendia modificar as convicções morais dos jurados a respeito do gênero, da sexualidade ou, mais contundentemente, da homossexualidade: "independente de aceitarmos ou não a questão de opção sexual, independente de que cada uma de Vossas Excelências tenha seus próprios conceitos", era preciso condenar aqueles dois homens que, segundo dizia, haviam matado uma pessoa. A relevância da vida carecia de ser resguardada. "Não se pode matar uma pessoa por isso".

\section{Gabriele "Eles": sobre vítima e algozes}

O júri a respeito do "caso Gabriel" ficou conhecido como o primeiro júri popular a tratar de um homicídio motivado por homofobia em Pernambuco. Os veículos de comunicação locais, jornalísticos e televisivos, definiram a condenação dos dois réus como um "marco" ou um "desfecho histórico" na luta do Movimento de Lésbicas, Gays, Bissexuais, Travestis e Transexuais no estado. Assim, a "homofobia" saiu das palavras de ordem $e$ das denúncias provocadas pelo Movimento LGBT, das explicações de Rosa sobre a razão da morte do seu filho, passou pela segunda delegada de polícia a investigar o caso, pela acusação desempenhada pelo promotor de justiça, até que chegou às 
manchetes dos noticiários. Como visto, porém, essa trajetória, das palavras de ordem à midiatização da condenação, confrontou disputas em torno da possibilidade de reconhecimento da causalidade da homofobia.

A primeira delegada que lidou com o "caso Gabriel" recusou a hipótese de que a homofobia havia influído no assassinato e solucionou as investigações como se o caso se tratasse, tão somente, de mais um dos corriqueiros casos relacionados ao que frequentemente se chama de "envolvimento com drogas" - ainda que "indireto"... - e à "pegação", o que sugere "prostituição", embora Rosa empregue a expressão "exploração sexual". ${ }^{10}$ Logo, nas conclusões da delegada, a vítima se encontrava entre a criminalização e o estigma, o que narrativamente convertia Gabriel numa "menos vítima", ou numa "não vítima", alguém que, ligado a drogas e práticas sexuais moralmente questionáveis, acabou contribuindo para as condições que levaram à sua morte. Culpado, portanto. Aqui se iniciam os esforços de Rosa com vistas à legitimação de Gabriel, à constituição do seu menino como uma vítima, esforços esses

\footnotetext{
${ }^{10} \mathrm{O}$ texto do Código Penal Brasileiro indiferencia as noções de "prostituição" e "exploração sexual". Dentre os crimes contra a "dignidade sexual", está, afinal, o de "favorecimento da prostituição e de outras formas de exploração sexual", do que se presume ser a prostituição uma delas. Embora a prática da prostituição não consista num tipo penal - de antemão, os legisladores brasileiros não fizeram da prostituição um crime - quase tudo em seu entorno é criminalizável. Ao falar das "meninas da Ceasa", Rosa se refere à "exploração sexual" provavelmente em razão de se tratarem de crianças e adolescentes. No caso de Gabriel, no entanto, a operação narrativa é outra. Ela parece estar diferenciando o seu filho dos sujeitos que submeteriam as meninas à exploração, ao tempo que maneja convenções morais acerca da sexualidade para alcançar a legitimidade de Gabriel na condição de vítima. Para debates a respeito dos conflitos sociais e políticos que rondam a prostituição, ver, por exemplo, os trabalhos essenciais de Adriana Piscitelli (2013) e José Miguel Nieto Olivar (2013). Já para discussões sobre a relação entre a atividade da prostituição e a figura da "vítima", abordando especialmente a questão do "tráfico de pessoas", ver os trabalhos conjuntos de Adriana Piscitelli e Laura Lowenkron (2015) e de Thadeus Blanchette e Ana Paula da Silva (2011).
} 
correlatos à caracterização da homofobia como causa do homicídio.

Como pude discutir em outra oportunidade (Efrem Filho, 2016), conflitos como esse acerca de Gabriel são comumente narrados por militantes do Movimento LGBT e se reproduzem nos autos dos inquéritos policias e processos judiciais com que me deparei durante a minha pesquisa de campo na Paraíba, mas também naqueles autos analisados pelos trabalhos fundamentais de Sérgio Carrara e Adriana Vianna (2006; 2004), no Rio de Janeiro, e, mais recentemente, pela dissertação de mestrado de Diego Lemos (2017), no Recife. Não é raro, desse modo, que uma violência compreendida pelos militantes como homofóbica seja resumida a crimes, como roubos ou tráfico de drogas, do que se depreende a criminalização da vítima, como dito, e a sonegação da homofobia. Tal qual não é raro que, diante dessas circunstâncias, os sujeitos preocupados com a legitimação da vítima se dediquem a apontar a excepcionalidade dos "fatos" sob disputa, sua inadmissibilidade.

Para isso, eles tendem a acionar "imagens de brutalidade" $e$, dessa maneira, a investir narrativamente na brutalização do corpo vitimado - "o meio cruel, não há o que se discutir. Bem observado o que fizeram com a cabeça da vítima" - enquanto manejam as convenções morais disponíveis às trincheiras do conflito. O manejo dessas convenções pode, por exemplo: afetualizar a vítima, aproximá-la da noção de "família" - "meu filho era amado"; trazê-la para dentro de casa - "até porque eu conhecia também. Gabriel saía pra casa dos amigos. Gabriel não dormia fora"; livrá-la da acusação do que poderia ser tomado como "desvios morais" - "porque se fosse um menino que tivesse esse vício de dormir fora de casa, eu também não tinha nem me importado"; afastá-la da criminalização, vinculando-a intimamente à figura da "mãe" - "meu filho não tava envolvido com droga, porque eu conhecia Gabriel, ele não tava envolvido com droga"; ou, ainda, adaptar-se às situacionalidades do conflito, como à audiência de um tribunal do júri - "independente de aceitarmos 
ou não a questão de opção sexual, independente de que cada uma de Vossas Excelências tenha seus próprios conceitos".

Tornar a vítima passível de adequação ao modelo de "vítima", contudo, requer a explicitação da violência, mas notadamente a caracterização das causas que fazem daquele caso notável, não apenas mais um encerrável no carimbo genérico do "envolvimento com drogas", e sim um problema merecedor de atenção das instâncias de Estado e mobilizador de políticas públicas, por exemplo. É do que se trata a apresentação da homofobia como "chave explicativa" para a violência. Como venho argumentando (Efrem Filho, 2017a; 2016), a chave explicativa da homofobia ilumina as relações de gênero e de sexualidade que permitem a morte, ensejam a sua possibilidade e, em determinados contextos, impedem a "inteligibilidade da vida", como diria Judith Butler (2010a; 2009). Ao reivindicar a homofobia como razão do assassinato, portanto, está-se a explorar as dimensões de gênero $e$ de sexualidade da violência $e$, necessariamente, da vítima e das experiências que engendrariam sua vulnerabilização.

A homofobia, porém, não basta. Disso eu me convenci rapidamente, logo que comecei a debulhar as narrativas sobre violência que emergiam em meu trabalho de campo. Essas narrativas, anunciei nas primeiras páginas deste artigo, compõemse das reciprocidades constitutivas entre relações sociais. Nas narrativas de Rosa, como nos autos do processo judicial e na sessão do tribunal do júri, o assassinato de Gabriel tanto se confrontava com relações de gênero e de sexualidade - Galo "falou da raiva que sentiu ao ouvir dizer que Gabriel teria espalhado haver transado com ele" - quanto com relações geracionais, territoriais, de classe, racialização etc. que conformam Santana e coligam Gabriel às inúmeras outras vítimas de violência presentes nas narrativas de Rosa sobre sua própria trajetória de vida e luta.

As meninas do "grupo cooperativo" da paróquia que contavam histórias sobre o "Caminhão do Faustão" estão entre essas vítimas, assim como Fernanda e Felipe, os estopins 
narrativos de Rosa, ambos mortos pelos integrantes dos Power Rangers. Se relações de gênero e de sexualidade tocam mais explicitamente as narrativas sobre as mortes de Gabriel e daquela menina encontrada sob o viaduto da Ceasa, tais relações não deixam de ser reciprocamente constituídas, por exemplo, pelas relações territoriais que afetam o assassinato de Fernanda, associado ao controle da gestão dos conflitos em Santana e à necessidade de demarcação dos limites porosos entre Victor, os membros do chamado grupo de extermínio e os agentes policiais procurados por Fernanda para a denúncia dos responsáveis pelo assassinato do seu irmão. Essas mesmas reciprocidades constitutivas entre relações de gênero, sexualidade e territoriais se encontram na justificativa dúplice de Rosa para a morte do seu menino. Gabriel morreu por homofobia. Mas não só. Segundo Rosa, Gabriel morreu em decorrência de um gesto de ameaça contra Rosa, em razão de sua militância pelos Direitos Humanos e de suas próprias denúncias contra as violências perpetradas em Santana.

As reciprocidades constitutivas entre as relações sociais que tramam as narrativas sobre Santana atrelam Gabriel a outras vítimas, como notei. Entretanto, perigosamente, essas mesmas reciprocidades também expõem laços entre Gabriel e outras personagens que perfilam o "caso", inclusive aquelas que seriam os seus algozes. De fato, naquela sessão do tribunal do júri de 17 de junho de 2015, essa perigosa proximidade entre Gabriel, Porco e Galo cintilava. A vítima e os réus eram jovens. Como dito, Gabriel tinha apenas 24 anos em outubro de 2010, o mês de sua morte. Quando do julgamento, em junho de 2015, Galo e Porco possuíam 25 e 26 anos respectivamente, ou seja, eram mais novos que Gabriel. As testemunhas apresentadas em vídeo aparentavam rondar idades similares. Eram igualmente mais jovens que Rosa, o juiz, o promotor, a defensora pública e que eu mesmo. De modo análogo, a maior parte desses sujeitos, inclusive Rosa, poderia ser compreendida como "negra", ou, no mínimo, como pessoas de pele mais escura que a do juiz, a do promotor, a da defensora pública e que a minha própria. Assim como a "geração" e a 
"raça", o "território" e a "classe" também circundam a vizinhança, o fato de quase todas as personagens do "caso Gabriel" serem classificáveis como "pobres", trabalharem na Ceasa, comercializando gêneros alimentícios ou descarregando caminhões, e habitarem um bairro periférico da cidade do Recife. Galo e Porco, afinal, haviam sido um dos meninos das narrativas de Rosa, amigos dos seus filhos desde a infância.

$\mathrm{Na}$ estratégia acusatória adotada pelo promotor de justiça, essas proximidades operavam ambiguamente. Serviam para demonstrar a "periculosidade" dos dois réus, que "desprezavam" uma vida tão próxima; no entanto, explicitavam sobremaneira que Galo, Porco, Gabriel e seus irmãos - um dos quais, segundo Porco, teria sido induzido por ele a roubar - achavam-se próximos demais em suas experiências, imbricados, em algum sentido talvez indiscerníveis. É se valendo dessa indiscernibilidade que a primeira degelada de polícia a atuar nas investigações do "caso Gabriel' chega à mencionada conclusão corriqueira de que Gabriel estaria "indiretamente envolvido com drogas". Claro, tal conclusão é excessivamente imprecisa e genérica: o que significa, enfim, "indiretamente"? a Delegada pretende sugerir que Gabriel comercializava drogas ilícitas, que ele consumia essas substâncias ou que convivia com pessoas que as comercializavam e/ou as consumiam? Não é possível saber. Mas é possível perceber a automaticidade burocrática dessa conclusão, a facilidade com que o caso de homicídio do menino de Rosa é alocado indiscernivelmente - como mais um caso, dentre tantos casos, a receber o selo do "envolvimento", ou seja, a restar associado ao mercado de drogas ilícitas, ao crime.

\section{5. "Ladrão normal": sobre crime}

No Relatório Final da Comissão Parlamentar de Inquérito sobre os Grupos de Extermínio no Nordeste, consta o depoimento do Delegado da Polícia Civil Ítalo Souto. Frente à comissão, Souto relatou a existência de referências, no município de Itambé, a assassinatos de homossexuais. Ele alegou, porém, que o único 
caso concreto com que se deparou, o da morte do homossexual Aroldo do Maracatu, estaria ligado não à sexualidade da vítima, mas à sua relação com o tráfico de drogas. De pronto, eu desconsiderei essa afirmação. Como notei acima, o atrelamento de LGBT a atividades criminosas costuma ser acionado segundo estratégias de desqualificação da vítima e o depoimento do delegado me parecia reproduzir esse acionamento. Porém, depois do começo do trabalho de campo e sobretudo após o meu encontro com as narrativas de Rosa sobre Santana, voltei à afirmação de Souto com outro olhar. Ao subestimar as reciprocidades constitutivas entre as relações sociais, eu reincidia na mesma dualidade posta pelo delegado: ou sexualidade, ou crime. Ele apostava no crime, eu apostava na sexualidade como causa da morte. "Ambas reciprocamente constituídas" não consistiam numa hipótese possivel.

As reciprocidades constitutivas entre as relações sociais que tramam as narrativas sobre Santana atrelam Gabriel a outras vítimas, a seus algozes e, consequentemente, ao crime. Não quero com isso dizer que Gabriel haja cometido crimes ou que ele tenha realizado o fato típico, antijurídico e culpável, como se costuma definir "crime" nos manuais de introdução ao Direito Penal. Tampouco pretendo conferir razão à primeira delegada. As narrativas que compõem o "caso Gabriel' não sugerem qualquer "materialidade" ou "nexo de causalidade" àquela alegação de "envolvimento". Quero dizer, no entanto, que, tendo ou não praticado atividades ilegais, envolvendo-se ou não com o consumo ou a comercialização de drogas ilícitas, Gabriel consiste num sujeito facilmente (ou automaticamente) criminalizável.

Isso porque crime é inexoravelmente criminalização. É relação social. Acha-se imbricado às experiências de constituição dos sujeitos - daí Michel Misse (2010) falar em "sujeição criminal" -, às relações sociais por eles partilhadas no seio das reciprocidades de que venho tratando. $\mathrm{O}$ crime é o sujeito. Corporifica-se. Está na idade de Gabriel, em suas experiências de racialização, no bairro onde habita, ainda que não esteja. Descumprimentos de normas são praticados em muitos graus por 
muitas pessoas. "Crimes", contudo, procedem de "descumprimentos" criminalizáveis cometidos por sujeitos criminalizáveis, os quais são selecionados por aquela gestão diferencial dos ilegalismos de que tratou Michel Foucault (2008) $e$ que os trabalhos de Gabriel Feltran (2011) captaram tão bem.

$\mathrm{Na}$ trajetória dos filhos de Maria, fica claro que o foco da repressão policial não é o ato infracional, mas o indivíduo que o pratica. O verbo empregado é o ser. Se é bandido, o sujeito passa a conter o ato ilegal em sua natureza: seu corpo passa a demonstrar o indivíduo ilegal, e é ele quem passa a ser um fora da lei. A nomeação não permite um contra-argumento. Absoluto no corpo do praticante, o ato ilícito passa também a comandar o olhar das forças da ordem para os corpos daqueles que lhe são semelhantes (Feltran, 2011:132).

Páginas atrás, ao alegar a premência e a insuficiência da chave explicativa da homofobia para a análise das narrativas sobre o "caso Gabriel", posicionei-me pela necessidade de situar essas narrativas no imo das reciprocidades constitutivas das relações sociais. Disse, então, que as narrativas acerca da morte do filho de Rosa concernem a relações de gênero e de sexualidade, o que justifica o recurso compreensivo à homofobia, mas também, por exemplo, a relações geracionais, de racialização, territoriais e de classe. Para ressaltar a participação da "classe" nessas reciprocidades, mencionei as proximidades das personagens do "caso" em torno de suas moradias, do dado de que todas elas compartilham o mesmo bairro numa região periférica do Recife. Notei ainda que são pessoas classificáveis como "pobres", ou pertencentes a setores precarizados da classe trabalhadora, e que as narrativas indicam que parte dessas pessoas se dedica a atividades laborais junto à Ceasa. Não notei, todavia, que essas relações de classe - necessariamente "trabalho", ou, seguindo Ricardo Antunes (2010), aquilo de que se vive - se abrangem o descarregamento de caminhões, também 
podem abarcar "injustamente" a atuação no mercado de drogas ilícitas ou a prática de roubos. ${ }^{11}$

Na sessão do júri do caso do homicídio de Gabriel, Galo e Porco foram chamados ao interrogatório. Apenas um deles, não lembro qual, decidiu falar, responder às perguntas do magistrado. Numa dessas perguntas, o juiz questionou sobre os processos judiciais a que os réus respondiam, a quantidade de roubos que haviam cometido $e$ o motivo de haverem sido presos anteriormente. O rapaz reconheceu a autoria dos roubos. Com firmeza na voz, sem hesitação ou qualquer intenção de arrependimento, contabilizou diante do juiz, do promotor, dos jurados e da plateia em geral, a quantidade de assaltos em que se envolvera. Havia cometido nove ou mais. Afirmou, contudo, não ter matado Gabriel. Era um "ladrão normal", não um assassino. O magistrado aparentou surpresa com a resposta, com a postura do rapaz que assumia publicamente a dedicação a atividades ilegais. Num perceptível tom jocoso, o magistrado então questionou o rapaz a respeito da "normalidade" com que reconhecia ser ladrão. Ele, novamente sem hesitar, ouvindo algumas risadas vindas da plateia, manteve o posicionamento inicial. Explicou, didaticamente, ao juiz que um "ladrão normal" era alguém que roubava, que praticava assaltos para viver, mas que não excedia esse "crime", não matava.

De fato, não é possível saber se Galo e Porco são tão somente "ladrões normais". Como visto, as histórias contadas por Rosa denunciam o contrário. Porco, afinal, havia sido um dos responsáveis pelo assassinato de Felipe, com um tiro nas costas e dois na cabeça, defronte à casa de Rosa, bem antes da morte de Gabriel. É possível, todavia, considerar o constrangimento gerado pela enunciação, no interior de um tribunal, da "normalidade" do crime. Essa "normalidade" distingue quem apenas rouba de quem

\footnotetext{
${ }^{11}$ Esse modo de compreender o conceito de "classe" toma como referência os sentidos do "fazer da classe" de que se valeu E. P. Thompson (1987, 1997) em suas análises. Para uma discussão mais aprofundada a esse respeito, ver: Efrem Filho (2017a, 2014).
} 
mata, mas expõe, acima de tudo, que o crime não consiste numa excepcionalidade, que ele pode ser compreendido conforme algo corriqueiro, comum, "normal", a que alguém pode se dedicar normalmente. Ou, melhor dizendo, "como um trabalho", para citar Marcela, uma de minhas interlocutoras de pesquisa (Efrem Filho, 2017a; 2014), então moradora de uma ocupação de semtetos, que participou durante alguns anos do que em João Pessoa se chama de "vida errada", dedicando-se à venda de drogas ilícitas.

A expressão "ladrão normal", portanto, complexifica dicotomias fundamentais para as instâncias de Estado e para determinadas convenções morais, como a dicotomia que separa diametralmente "trabalhadores" de "bandidos". A possibilidade narrativa da referência à personagem do "ladrão normal", exposta sem os pudores característicos a ocasiões solenes, exibe as fragilidades da mencionada dicotomia ao passo em que aponta para experiências de classe que se dão no trânsito entre trabalhos legais e ilegais, entre o descarregamento de caminhões e a comercialização de substâncias ilícitas. Minha compreensão a respeito dessas experiências, que atravessaram as narrativas com que me deparei no transcurso de meu trabalho de campo, adveio do contato com pesquisas, sobretudo no campo dos estudos sobre cidades e periferias, que me ajudaram na percepção dos câmbios identitários entre trabalhadores e bandidos e dos trânsitos entre trabalho e crime. Dentre essas pesquisas, encontram-se principalmente os trabalhos já mencionados de Gabriel de Santis Feltran $(2011,2010)$ e aquelas desenvolvidas por Vera da Silva Telles e Daniel Veloso Hirata.

Os trabalhos confluentes de Vera da Silva Telles (2010, 2013) e Daniel Hirata (2010) e os seus textos de autoria compartilhada (Telles; Hirata, 2007, 2010) não só adensam a complexificação daquela dicotomia, como, em diálogo com os argumentos de Vincenzo Ruggiero $(2000,2007)$ e de Ruggiero e Nigel South (1997), aproximam-se analiticamente do crime "como um trabalho". Nesse sentido, Telles e Hirata afastam-se da pressuposição de existência de dois sujeitos exteriores e oponíveis 
um ao outro, o criminoso externo e oposto ao trabalhador, e passam a observar o

trabalhador urbano que transita nas fronteiras incertas entre o ilegal, o informal e o ilícito, lançando mão de forma descontínua $e$ intermitente das oportunidades legais $e$ ilegais que coexistem $e$ se superpõem nos mercados de trabalho (Telles; Hirata 2010:40).

Esses deslizamentos corriqueiros entre o legal, o ilegal e o ilícito preenchem "uma zona cinzenta que torna incertas $e$ indeterminadas as diferenças entre trabalho precário, o emprego temporário, expedientes de sobrevivência $e$ as atividades ilegais, clandestinas ou delituosas" (Telles e Hirata, 2007:173). Não há aqui, como se vê, espaço para a personagem midiática do bandido, "o traficante", criado à imagem e à semelhança do grande inimigo, a encarnação do mal, do "Crime Organizado", essa entidade em letras maiúsculas, justificativa para práticas de repressão e gestão populacional. Pelo contrário, há sujeitos que, como enfatizou Daniel Hirata (2010), "sobrevivem na adversidade", vivem de seu trabalho, nas dobras do legal e do ilegal, movem-se entre riscos, precisam responder adequadamente a diferentes esferas de valores e convivem com a possibilidade iminente do confronto $e$ da morte.

O crime não constitui o elemento distintivo central entre os filhos de Rosa e aqueles que, um dia, também foram seus meninos em Santana. Pelo contrário, o crime os aproxima, mesmo que, como já ressaltei, Gabriel nunca tenha praticado roubos ou adentrado o mercado varejista de drogas ilícitas. A criminalização é parte das experiências comunitárias vivenciadas por esses sujeitos. É verdade, Rosa se vale de distintos "marcos discursivos", como Feltran (2011) os define, que se antagonizam narrativamente. De um lado, há o marco relativo ao "mundo do trabalho" e ao "mundo religioso", de outro, há o marco do "mundo do crime". Mas, nas trincheiras dos conflitos, tais distinções se materializam em disputas territoriais sobrepostas, de 
difícil diferenciação. Santana concerne a um território sob disputa. Mas não se trata de um território disputado entre "trabalhadores" e "bandidos". Essa é a disputa travada na superfície, na primeira pele das narrativas. Rosa não representa uma "trabalhadora" que luta contra "criminosos". "Sempre eu fui referência pra pedir ajuda de mãe, de filho, de tudo. Quando tinha um adolescente preso na comunidade: 'vamo lá em Rosa'". Rosa arregimenta suas próprias armas contra aquilo que ela apreendeu, na luta, como sendo "violência".

\section{Cipó de boi e meninos. sobre violência}

As disputas territoriais que constituem Santana nas narrativas de Rosa são entrecruzadas às violências, às mortes, à exploração sexual das meninas, aos grupos de extermínio, aos justiceiros, aos meninos atraídos por esses grupos e por policiais, aos vínculos corruptores que envolvem "agentes de Estado" às tramas das violências. "Essa senhora de quem ele disse horrores aqui é a mesma que ele disse que ajudou ele" - notou o promotor de justiça durante a sessão do júri de 17 de junho de 2015. "Com essa mesma advogada, (Rosa) conseguiu a liberdade do Galo no passado". Nas ambiguidades de suas narrativas, Rosa se opõe à violência. Por isso, a sua tomada de posição contra os Power Rangers. Por isso, as mortes de Felipe e Fernanda, em Santana, exsurgem narrativamente como um "estopim". A violência está no cerne, o crime não. "Normalmente" ou não, "injustamente" ou não, o crime e a criminalização atravessam a sua vida, a sua família, a casa para onde ela precisou trazer Gabriel em razão da premência de sua legitimação na condição de "vítima".

É em suas histórias sobre as violências - das surras do pai em seu irmão e em sua mãe até as mortes de Fernanda e Felipe que as reciprocidades constitutivas entre as relações sociais, de classe e sexualidade, de gênero e territoriais, evidenciam-se mais claramente, performatizando o excesso, o absurdo, o inadmissível. Embora Rosa se movimente narrativamente para impedir a criminalização de seu filho e, em consequência, a sua 
deslegitimação, não é o crime, insisto, o que diferencia Gabriel dos acusados pelo seu assassinato. É a inadmissibilidade histórica da violência, aquilo que não se deve suportar ou permitir que aconteça novamente. Perceber isso, contudo, apreender as conexões e distinções entre crime e violência exigiu de mim um movimento analítico semelhante àquele desenvolvido por Guita Grin Debert e Maria Filomena Gregori (2008) quando de sua análise acerca dos debates sobre a Lei Maria da Penha e seus efeitos junto ao sistema de justiça.

Segundo Debert e Gregori, "crime implica a tipificação de abusos, a definição das circunstâncias envolvidas nos conflitos e a resolução destes no plano jurídico". Violência, por sua vez, concerniria a outros embates, a uma inteligibilidade não necessariamente estatal.

Violência, termo aberto aos contenciosos teóricos $e$ às disputas de significado, implica o reconhecimento social (não apenas legal) de que certos atos constituem abuso, o que exige decifrar dinâmicas conflitivas que supõem processos interativos atravessados por posições de poder desiguais entre os envolvidos (Debert; Gregori 2008:176).

Claro, o que Debert e Gregori identificam como "crime" não coincide imediatamente com o que eu venho denominando de crime e criminalização.

Nas discussões travadas em seu texto, as duas autoras se veem imersas nas contendas sobre a Lei Maria da Penha, preocupam-se com o "encapsulamento da violência pela criminalidade" (Debert; Gregori 2008:166) e conferem ao "crime", desse modo, uma legibilidade estatal que, embora produza sentido e eficácia naquele contexto de que elas se ocupam, conforma apenas uma das dimensões do que se pode denominar como "crime", um termo tão aberto a disputas de significado quanto "violência". O crime tomado como criminalização - ou como processo de criminalização, relação social - referencia-se em normas estatais e morais, confronta marcos discursivos relativos ao 
trabalho, à família e à religião, mas consiste sobretudo em experiência. Por isso, o crime é "tipo um trabalho", reúne pesos morais distintos a depender da atividade em questão - matar, roubar ou vender -, intersecta a família, atrela-se narrativamente a uma "normalidade". Novamente, o crime experiencia relações sociais e constitui essas relações sendo reciprocamente constituído por elas.

De certo, as distinções entre crime e violência não são diametrais. Pelo contrário, submetem-se a conflitos de diversas ordens, de regra associados às formas estatais de inteligibilidade. Acontece que, de acordo com essas formas, a violência costuma só produzir sentido se for capaz de preencher um "tipo penal", ou seja, se ela corresponder ao que juridicamente se reconhece como crime. O assassinato de Gabriel, portanto, precisa ocupar um lugar normativo, no caso, o artigo 121 do Código Penal, em que se prevê - como dizem os juristas - o crime de homicídio. Diante dessa forma de inteligibilidade acerca da relação entre crime $e$ violência, não há espaço para a definição do crime como criminalização, relação social, sujeição ou experiência. Tampouco resta espaço para a leitura de violências que não se adequem a um tipo, a uma norma legal.

Nas narrativas de Rosa sobre a morte do seu menino, entretanto, a violência arrasta muitíssimo mais elementos do que a exegese do Código Penal comportaria. $\mathrm{O}$ rabo de timbu não cabe no tipo. O tipo não comporta Fernanda e Felipe, os Power Rangers e todo o emaranhado de inadmissibilidades que arquitetam o "caso Gabriel" e a dúplice justificativa de Rosa para o assassinato, tudo aquilo que distingue o caso do seu filho dos numerosos e cotidianos homicídios em que o recurso automático ao "envolvimento com drogas" parece servir de explicação. Por outro lado, nessas mesmas instâncias de Estado, práticas como o roubo ou o tráfico de drogas, normativamente perceptíveis como "crime", são muitas vezes tomadas como violência - há até quem fale em "violência patrimonial" -, a ponto de, como já debati, a expressão "ladrão normal" soar intraduzível. 
Porém, para além das formas estatais de inteligibilidade, os conflitos sobre os limites distintivos entre crime e violência também alcançam as experiências dos sujeitos. Em que momento Porco e Galo deixam de ser os meninos de Santana a quem Rosa ajudava e se tornam integrantes do grupo de extermínio? Quando eles abandonam o lócus narrativo do "menino que dá problema" ou do "menino envolvido com coisa errada", como é comum se falar no Recife, para se tornarem "assassinos cínicos", "perigosos" e "debochados"? Um dos primeiros episódios de violência presenciados por Rosa, quando do início de seu pertencimento à luta, logo após a sua chegada no Recife da década de 80 , sugere alguns caminhos interpretativos para essa distinção.

Soube-se que um rapaz - um menino, nos dizeres de Rosahavia furtado uma vaca. Um grupo de outros jovens - Rosa os chama de justiceiros - decidiu punir o rapaz. Ele foi então surrado em meio às ruelas não asfaltadas de Santana. Para a execução da surra, os jovens se valiam de um "cipó de boi", um instrumento elaborado a partir do couro, esticado e curtido, da genitália do boi morto. Após as chicotadas, levaram o rapaz, "agonizando", para uma mata próxima, onde enterraram o seu corpo, mantendo apenas a cabeça sobre a superfície. "Ele morreu lá, desse jeito. Não enterraram todo, pra não dizer que enterraram vivo. Deixaram o menino enterrado só com a cabeça pra fora $e$ foram embora. Ninguém podia chegar lá. Ninguém chegava. Todo mundo tinha medo". Mas a notícia do assassinato do menino não demorou a chegar à polícia que, por sua vez, conseguiu apanhar um dos jovens. Esse novo menino, antes executor, migrou para a condição de vítima. Os policiais obrigaram o rapaz a deitar no chão, também na rua, e o atropelaram com uma motocicleta. A moto passou sobre sua barriga. Depois, levaram-no à delegacia $e$, segundo me contou Rosa: "ele foi preso e a polícia disse que foi tortura mesmo porque deram óleo queimado e ele adoeceu $e$ morreu".

O menino presume a vítima. É tramado em relações de gênero e geracionais que acusam a sua fragilidade. Remete a uma linguagem de gênero e sexualidade, ou nada explicaria a 
"necessidade" de empregar o couro da genitália de um animal para surrar outro homem, um trabalhador, um ladrão. Recende a conflitos territoriais pela gestão da comunidade, da administração e da configuração de domínios. Performatiza relações de classe e racialização, às quais também se adere o "cipó de boi", essa ferramenta, quase mitológica, manuseada pelos "senhores" $e$ "coronéis", ou por seus capangas, contra os corpos de escravos ou trabalhadores. O menino é narrativamente constituído pela experiência da violência. Haver furtado ou roubado uma vaca não o retira desse status. A prática da violência, sim. "Rapaz, vamo chamar a mãe dele?". "Não, deixe a mãe dele dormindo. Ele tá num sono tranquilo, um sono eterno". "O Porco dizia isso. E eu não sabia que ele ia ser o assassino do meu filho. E ele debochava do menino". A prática do que excede, sim.

\section{7. "Se trata de demonstrar quem são": sobre processos de Estado}

A conclusão analítica de que, nas falas de Rosa e de outros interlocutores de pesquisa, o crime não representa o problema narrativo por excelência, mas sim a violência, não se demonstra produtiva no interior das lógicas de Estado ou nas páginas numeradas dos autos de inquéritos policiais e processos judiciais. Ela não faz sentido. Nesses ambientes, requer-se de costume a extrema disjunção entre vítimas $e$ algozes, a assunção de personagens arquetípicas que precisam desempenhar nas "fábulas", como as nomeou Mariza Corrêa (1983), papéis relativamente aguardados, estruturados narrativamente em "fatos" que devem se conectar linearmente ou, como percebeu Larissa Nadai (2016), através da produção de uma "coerência" que justifique, por exemplo, os "nexos de causalidade". Argumentar em torno das proximidades das experiências que fazem de Gabriel, Galo e Porco sujeitos criminalizáveis, ou das experiências que fazem deles meninos e não mais meninos, escapa aos sentidos formais de Estado. E, de fato, se o argumento em questão for mal empenhado, pode-se colocar em risco os esforços de constituição da vítima - não à toa, Rosa precisou, como dito, dedicar-se a 
legitimar Gabriel, afastá-lo do crime; não à toa, o conflito de Rosa com os Power Rangers não emergiu durante o júri, ele prejudicaria a coerência que a homofobia conseguiu tecer. No entanto, apesar da ausência de sentidos e dos riscos implicados nessa conclusão analítica, ela me parece produtiva à medida que projeta luz sobre os meninos de Rosa, mas também sobre aqueles que friccionam essa identidade.

Lá, sentado no auditório do Fórum Thomaz de Aquino, assistindo ao júri, eu não conseguia evitar o pensamento de que nós estávamos ali, como num roteiro previsível e predefinido, presenciando a punição dos puníveis, a criminalização dos criminalizáveis. Agora, porém, após percorrer todo o corpus narrativo que me possibilitou escrever este artigo, mas antes, os três capítulos da tese, a questão assume uma nova perspectiva. A punição de Galo e de Porco continua sendo a punição dos puníveis, a criminalização dos criminalizáveis. Entretanto, enquanto as disputas narrativas protagonizadas por Rosa se deslocam para os contornos da sessão do tribunal do júri e para a fala pública do promotor de justiça, uma série de outros sujeitos a priori puníveis e criminalizáveis são discretamente vocalizados, legitimados na cena pública. É o que ocorre com algumas testemunhas. Apesar do constrangimento provocado pela assunção despudorada da "normalidade" do crime, foram "criminosos" os garantidores das provas testemunhais empregadas pelo promotor para sustentar a acusação contra Galo e Porco. Sem as palavras de Jonildo e Flávio, sem que Jonildo houvesse observado os "sorrisos com ar de deboche", sem que Flávio tivesse escutado Galo assumir o assassinato, não haveria muito a alegar por parte da acusação.

O assassinato de Gabriel não deixou "provas materiais" substanciais. Tampouco alguém assistiu à execução dos chutes $e$ golpes que causaram o traumatismo craniano. Rosa e o promotor, desse modo, dependiam dos testemunhos de dois detentos para alcançar a punição de outros dois detentos. É assim que, na sustentação oral do promotor de justiça, os dois primeiros são investidos de legitimação. Jonildo se torna aquele que, com 
coragem e respeito a Rosa, volta atrás em seu depoimento inicial, desafia as ameaças feitas contra ele e decide contar o que sabia. Flávio, por sua vez, é tecido narrativamente como alguém que sofreu ao saber da autoria do assassinato de Gabriel, de quem gostava. Como dito, de acordo com o trecho do testemunho selecionado e lido pelo promotor, Flávio sentiu raiva, passou duas noites calado, sem falar com ninguém. Os dois, assim, mostravamse profundamente "humanos", enquanto Galo e Porco, insubordinados mesmo durante a sessão do júri, sofrendo reprimendas do promotor e do juiz, não passavam de homens "debochados". "São cínicos, são debochados". "Perigosos", portanto.

Embora Galo tenha inicialmente, na delegacia de polícia, imputado a autoria do crime a Porco, as provas apresentadas contra os dois não são as mais sólidas. "Sorrisos com ar de deboche"; a entrada inexplicada de um dos dois rapazes na casa de Rosa, depois do desaparecimento de Gabriel, em razão de um aparelho celular; a própria afirmação de Flávio de que ouvira Galo, no presídio, assumir o assassinato; nada disso consiste em prova que impeça completamente, por exemplo, a aplicação do princípio jurídico do "in dubio pro reo" - ou seja, o princípio segundo o qual, por conta da presunção da inocência, se existe dúvida deve haver absolvição. A despeito disso, Galo e Porco foram condenados a dezoito anos de reclusão. Claro, também não é possível saber o que convenceu os jurados, se a estratégia desenvolvida pelo promotor de justiça, se a ambivalência dos posicionamentos dos réus, se sua condição "estrutural" de puníveis e criminalizáveis etc. Importa, porém, como dito, que os conflitos narrativos desencadeados acerca do caso promoveram a conversão de pessoas puníveis e criminalizáveis em pessoas admissíveis publicamente, legitimáveis para sua vocalização. Flávio e Jonildo são essas pessoas, mas o próprio Gabriel também.

$\mathrm{O}$ acionamento, pelo promotor de justiça, da homofobia como chave explicativa para o crime, ainda que tenha resguardado as posições pessoais dos jurados sobre a 
homossexualidade, "independente de aceitarmos ou não a questão de opção sexual, independente de que cada uma de Vossas Excelências tenha seus próprios conceitos", disputa a inteligibilidade da vítima em um sentido diverso daquele de que se valeu a primeira delegada a lidar com o caso. Gabriel partilhava de relações sociais bastante próximas às de Galo e de Porco. Em classe, eles se aproximavam. Em racialização e geração, eles se aproximavam. Talvez se aproximassem inclusive em sexualidade afinal, Galo e Porco mantinham ou não relações sexuais com Gabriel? Como visto, toda essa proximidade admitiu lastro para a criminalização do menino de Rosa. Naquela sessão do júri a que eu assistia, no entanto, Gabriel se tornava uma vítima inteligível de relações de gênero e de sexualidade tornadas visíveis $e$ reconhecíveis. Um menino - ou uma travesti, como alguns sujeitos a identificaram - "estruturalmente" punível, criminalizável $e$ morrivel passava a ocupar um outro lugar, o de uma vítima inteligível a partir das relações de gênero e de sexualidade que o forjaram vitimável. Do outro lado, em sua contraparte, encontravam-se dois homens que se valeram do inadmissivel, de "violência", "brutalidade", "homofobia", o que os diferenciaria narrativamente de Gabriel, mas também de Jonildo e Flávio, preso "injustamente" por "tráfico de drogas", convenhamos, um "crime normal".

A percepção dessa oportunidade de vocalização $e$ legitimação, em cena pública, de sujeitos a priori puníveis $e$ criminalizáveis ajuda a desvelar, também, algumas das dinâmicas que atravessam aqueles "sentidos formais de Estado" anteriormente mencionados. Esses sentidos, como argumentei, demandam rigidamente pares estáveis de opostos, como as figuras arquetípicas da "vítima" e do "algoz", do "trabalhador" e do "bandido", assim como requerem a conexão narrativa de "fatos" que precisam ser apresentados linearmente, garantindo sua coerência. Acontece, porém, que a rigidez da demanda consiste, igualmente, em objeto de conflitos nos processos de Estado. A rigidez é produzida, tal qual são produzidas as noções de dicotomia, estabilidade, linearidade, coerência etc. Quero com 
isso dizer que a rigidez das "lógicas de Estado" é parte do esforço de ideação constitutivo do "Estado-ideia" de que falou Philip Abrams (1988); e que ela, no entanto, cambaleia flagrantemente, por exemplo, diante das disputas acerca da designação de que "fatos" e "personagens" servem ou não para sustentar a "coerência" fundamental.

Apesar do espanto do juiz frente à afirmação de um dos réus de que ele - o réu - seria apenas um "ladrão normal" e não um assassino, foram, como expliquei, dois "ladrões normais" responsáveis pela produção de provas que avalizaram a coerência narrativa dos fatos que conduziriam à condenação dos réus. Dois "ladrões normais" se tornaram admissíveis publicamente. Com eles, o crime ("normal") também se tornou admissível, em contraste com o crime de que Galo e Porco eram acusados, uma violência. A disputa a respeito de que fatos e sujeitos podem funcionar na produção da coerência narrativa é tramada, como se vê, em relações de gênero. De pronto, porque a ideia de rigidez o é, ao lado da suposição de racionalidade - contrária à de pessoalidade, ou afetuosidade - que, em tese, compõe os procedimentos burocráticos. Além disso, porque a possibilidade de vocalização e legitimação da vítima e das testemunhas - os dois "ladrões normais" - acha-se diretamente ligada à possibilidade de sua caracterização como "inofensivos", "dóceis", não perigosos, o que os distancia, em gênero, do comportamento "debochado", "cínico", indisciplinado e, portanto, "perigoso" dos dois réus.

A posicionalidade dos termos da dicotomia "feminino $\mathrm{x}$ masculino" não coincide necessariamente, contudo, com a posicionalidade dos termos da dicotomia "vítima/testemunha $\mathrm{x}$ algoz". Pelo contrário, ambas as dicotomias são performatizáveis. De forma que se Jonildo é inicialmente arquitetado, nas narrativas do promotor de justiça, como alguém "não perigoso" que sentia medo de Galo e Porco, converte-se, logo depois, numa personagem corajosa que superou seu medo em nome do que the parecia justo, viabilizar a condenação dos culpados pela morte de Gabriel, ajudar Rosa. As personagens do conflito sofrem, sendo assim, transições de gênero. O mesmo se dá com Rosa. Ela 
encarna, também não é difícil perceber, a personagem da "mãe", aquela capaz do possível e do impossível pelo seu filho e que, portanto, não precisa responder a ideais de racionalidade $e$ coerência lógica. Rosa, entretanto, é muito mais que isso. Não corresponde àquelas mães que, como ela mesma diz, "não são cuidadas pelo Estado, não são tratadas pelo Estado". Nas palavras do promotor de justiça, como dito, ela é "quem ajuda", mas Rosa não ajuda "como uma mãe" simplesmente, ela "ajuda" como uma militante.

Esse é o desconfortável subtexto que atravessa todo o julgamento: a "militante" Rosa lateja sob a figura da "mãe" que pranteia a morte do seu menino; no entanto, ela precisa restar na penumbra, permitir que a "mãe" se sobressaia. A "militante" está ali, mas sua exposição, a da militante de esquerda que ingressou no Programa de Proteção aos Defensores de Direitos Humanos em razão das corajosas denúncias contra os Power Rangers, exporia, recíproca e perigosamente, os lugares de Galo e Porco no grupo de extermínio. Essa exposição poderia prejudicar, como aleguei anteriormente, a coerência da causalidade da homofobia. Ainda que as integrantes do Programa de Proteção e inúmeros outros militantes de Direitos Humanos estivessem na sala do tribunal do júri, ainda que Rosa estivesse acompanhada de policiais cuja função era assegurar a sua segurança, todas essas presenças, por mais explícitas que fossem, careciam de ser geridas com alguma discrição.

Todos esses conflitos perfazem processos de Estado $e$, tomados para análise, demonstram que os termos aparentemente mais rígidos desses processos e de seus sentidos e lógicas também se encontram sob conflito. São situacionalmente recompostos. Levada essa análise adiante, todavia, alcança-se, quase que consequentemente, outro par de termos opostos fundamentais à produção dos "sentidos formais de Estado": o par que conforma "o Estado" num dos extremos da díade, em oposição à noção de "sociedade civil", que ocupa o outro extremo. A noção de "sociedade civil", por sua vez, ora aparece como "a sociedade em geral", ora é apresentada como "a sociedade civil organizada", 
conceito que abarcaria sujeitos políticos como os movimentos sociais ou as organizações não governamentais.

Como notou Luciano Oliveira (2009) em seu trabalho sobre a tortura, porém, a oposição narrativa, típica aos nossos anos 70, "Estado-torturador versus sociedade civil-torturada" cede espaço para

uma relação bem mais complexa, talvez impossível de ser definida com um termo menos impreciso do que ambiguidade, pois ela varia da revolta explícita contra o massacre de Vigário Geral ao apoio tácito à chacina do Carandiru (Luciano Oliveira, 2009:37).

Em outras palavras, o comprometimento de determinados sujeitos, que segundo aquela oposição seriam enquadráveis como "sociedade civil", no manejo da violência - Oliveira fala das torturas, dos linchamentos, das execuções sumárias etc. complexifica o conflito em questão e impede a dicotomia. Sendo assim, obstaculiza também o acionamento daqueles modelos mais facilmente reconhecíveis de seus arquétipos. É preciso, então, compreender as relações de poder mais finas, discretas, cujas conexões, ou reciprocidades, permitem a visualização tanto do que Sílvia Aguião (2014) denominou de processos de "fazer-se no Estado", quanto daquilo que Juliana Farias $(2015 ; 2014)$ chamou de "engrenagem".

As disputas protagonizadas por Rosa em nome da constituição de Gabriel como uma vítima legível e da homofobia como chave de inteligibilidade para o "caso" se somam a inúmeras outras narrativas sobre violência, reivindicadas em meio às estratégias de luta por direitos e "justiça". ${ }^{12}$ Tais disputas, em

\footnotetext{
${ }^{12} \mathrm{Em}$ dois outros momentos (Efrem Filho, 2017a; 2017b), tratei mais detidamente das estratégias de lutas por direitos e "justiça" desencadeadas por meio da mobilização pública de emoções e do sofrimento, do "pranteamento coletivo da perda". Em diálogo direto notadamente com os importantes trabalhos de Paula Lacerda (2012), Adriana Vianna (2014) e Adriana Vianna e Juliana Farias (2011), discuti a relevância da figura da "mãe" nos meandros dessas lutas e na possibilidade de legitimação da vítima. Rosa, de certo, consiste num
} 
que atuam movimentos sociais os mais diversos $e$, inclusive, "movimentos de mães", participam profunda e inexoravelmente do que Sílvia Aguião tratou, habilmente, como processos de "fazer-se no Estado". Esse "fazer-se" remonta, de acordo com Aguião, às "formas através das quais o Estado produz os sujeitos que governa (administra)", mas também ao "processo de constituição desses sujeitos como parte de um fluxo contínuo de produção do próprio Estado" (Aguião, 2014:14). Através de um diálogo com os trabalhos, aqui já citados, de Philip Abrams (1988), Aguião toma "o Estado" não como uma estrutura fundamental e oculta que carece de desvelamento, mas como práticas políticas através das quais o Estado é forjado como um "ente", como aquela tal estrutura fundamental e oculta. "O estado como prática, o estado-sistema, seria a forma através da qual o estado-ideia é construído" (Aguião, 2014:14).

Os investimentos nas disputas das "narrativas de Estado", como é o caso da disputa pela possibilidade de o promotor de justiça se valer da palavra "homofobia" como chave de inteligibilidade para as causas do crime, constituem os sujeitos que lutam e a própria ideia de "Estado". Agora, todavia, penso ser necessário notar as correspondências entre essa ideia de "Estado" e os sujeitos que, aparentemente aquém ou além do que seria esse "Estado", movimentam as armas e a violência. Em seu estudo sobre a gestão das populações de favelas no Rio de Janeiro, Juliana Farias $(2015 ; 2014)$ compreendeu essas correspondências como as mencionadas "engrenagens" a partir de suas reflexões a respeito, por exemplo, da localização do "disparo do fuzil", realizado por um policial militar contra "moradores de favelas", como produto e produtor das políticas de segurança pública.

Segundo Farias, há um entrelaçamento entre o posicionamento institucional a respeito das mortes dos moradores de favelas e o que um promotor de justiça designou, durante o

contundente exemplo de acionamento dessa figura, aquela cuja dor é pressupostamente indiscutível, sendo ela, a "mãe", capaz de fazer o impossível pelo filho perdido. 
julgamento acerca do caso em que o referido fuzil foi disparado, como a "vontade livre e consciente de matar" realizada pelo policial executor do disparo.

Não há como (e esse não é um objetivo deste estudo) negar a implicação do policial que efetua o disparo fatal na engrenagem governamental que faz a gestão das mortes - a insistência dessa argumentação é para que não se deixe de enxergar a engrenagem (Farias, 2015:81).

Ou seja, a vontade individual de determinado policial não explica, sozinha, as mortes ou a gestão das mortes. É necessário considerar as conexões entre essa vontade, o disparo do fuzil e outras peças da engrenagem da gestão. Para ressaltar essa engrenagem, Juliana Farias (2014) articula o ato de execução sumária cometido pelo policial militar ao laudo cadavérico posteriormente elaborado por um agente de polícia civil. Nesse caso, as respostas mal formuladas do perito aos quesitos do laudo poderiam prejudicar concretamente a investigação e justificar a absolvição dos policiais acusados. Por isso, o ato de disparo do fuzil e o laudo cadavérico se articulam e compõem a "gestão" das mortes e das políticas de segurança.

Pois bem, talvez seja possível, talvez imprescindível, localizar o "rabo de timbu" e o "cipó de boi" também em meio às tais engrenagens. Victor, Galo e Porco não são policiais e, logo, não se adequam obviamente à noção de "agente de Estado", como se dá com os policiais militares que passaram uma motocicleta sobre a barriga do menino que, antes, havia participado do linchamento do outro menino, o que tinha furtado a vaca. São, todavia, homens implicados no mercado de drogas ilícitas, nas experiências do crime e da criminalização, relacionam-se, mais ou menos diretamente, mais ou menos mediatamente, com policiais $e$ agentes governamentais, como Rosa alertou, e, inexoravelmente, atuam na fabricação da imagem do "Estado", ainda que por contraste. Sendo aquilo que deve ser "excepcional" para ser combatido, são aquilo que pode ser "normal" e se faz constitutivo 
das práticas de Estado. Todos esses gestos de violência acabam por entrecruzar práticas e disputas de Estado e por ser tecidos nos interstícios das reciprocidades constitutivas das relações sociais. Mais do que isso. Todos eles passaram a consubstanciar narrativas sobre violência e, conseguintemente, a compor a inadmissibilidade mobilizada para a produção de políticas, por exemplo.

Enfim, o embate com os sujeitos acusados da execução da violência produz bem mais do que a punição dos puníveis $e$ a criminalização dos criminalizáveis. Ele não só possibilita a legitimação de outros sujeitos a priori criminalizáveis como expõe as contradições das práticas de Estado e as relações de poder - os conflitos de classe, de gênero, de sexualidade etc. - em que essas contradições se expandem. O embate "faz Estado", faz os sujeitos. Mas nesse processo não há apenas reprodução ou reafirmação de estruturas. Há disputa de hegemonia. Há história.

\section{Referências bibliográficas}

ABRAMS, Philip. Notes on the difficulty of studying the State (1977). Journal of Historical Sociology, vol. 01, n. 01, 1988, pp.58-89.

AguiÃo, Sílvia. Fazer-se no "Estado": uma etnografia sobre o processo de constituição dos "LGBT" como sujeitos de direitos no Brasil contemporâneo. Tese (Doutorado em Ciências Sociais), IFCH/Unicamp, Campinas, 2014.

ANTUNES, Ricardo. Adeus ao trabalho?: ensaio sobre as metamorfoses e a centralidade do mundo do trabalho. $14^{\mathrm{a}}$ ed. São Paulo, Cortez, 2010.

Blanchette, Thadeus Gregory; Silva, Ana Paula da. O mito de Maria, uma traficada exemplar: confrontando leituras mitológicas do tráfico com as experiências de migrantes brasileiros, trabalhadores do sexo. Revista Interdisciplinar de Mobilidade Humana, n. 37, Brasília,:2011, pp.79-105.

BRAH, Avtar. Diferença, diversidade, diferenciação. cadernos pagu (26), Campinas, Núcleo de Estudos de Gênero-Pagu/Unicamp, 2006, pp.329-376. 
ButLER, Judith. Marcos de guerra: las vidas lloradas. Buenos Aires, Paidós, 2010a.

- Problemas de gênero: feminismo e subversão da identidade. Trad. Renato Aguiar. $3^{a}$ ed. Rio de Janeiro, Civilização Brasileira, $2010 b$.

. Vida precaria: el poder del duelo y la violência. Buenos Aires, Paidós, 2009.

. Cuerpos que importam: sobre los limites materiales y discursivos del "sexo". Buenos Aires, Paidós, 2002.

CARRARA, Sérgio; ViAnNA, Adriana R. B. "Tá lá o corpo estendido no chão...": a violência letal contra travestis no Município do Rio de Janeiro. Physis: Rev. Saúde Coletiva, vol. 16 (2). Rio de Janeiro, 2006, pp.233 - 249.

"As vítimas do desejo": os tribunais cariocas e a homossexualidade nos anos 1980. In: PISCITELLI, Adriana; GREGORI, Maria Filomena; CARRARA, Sérgio (org.). Sexualidades e saberes: convenções e fronteiras. Rio de Janeiro, Garamond, 2004, pp.365383.

CORREAA, Mariza. Morte em família: representações jurídicas de papéis sexuais. Rio de Janeiro, Edições Graal, 1983.

DeBert, Guita Grin; GrEGORI, Maria Filomena. Violência e gênero: novas propostas, velhos dilemas. Revista Brasileira de Ciencias Sociais, vol. 23, n. 66. São Paulo, 2008, pp.165-211.

EFREM FILHO, Roberto. Mata-mata: reciprocidades constitutivas entre classe, gênero, sexualidade e território. Tese (Doutorado em Ciências Sociais), Instituto de Filosofia e Ciências Humanas, Universidade Estadual de Campinas, 2017a.

- A reivindicação da violência: gênero, sexualidade $e$ a constituição da vítima. cadernos pagu (50), Campinas, Núcleo de Estudos de Gênero-Pagu/Unicamp, 2017b, e175007.

. Corpos brutalizados: conflitos e materializações nas mortes de LGBT. cadernos pagu (46), Campinas, Núcleo de Estudos de Gênero-Pagu/Unicamp, 2016, pp.311-340. 
"Bala": experiência, classe e criminalização. Revista Direito e Práxis, vol. 05, n. 09. Rio de Janeiro, 2014, pp.501-537.

FACCHINI, Regina. Entre umas e outras: mulheres, (homo)sexualidades e diferenças na cidade de São Paulo. Tese (Doutorado em Ciências Sociais), IFCH/Unicamp, Campinas, 2008.

. Entrecruzando diferenças: mulheres e (homo)sexualidades na cidade de São Paulo. In: DíAz-BENITEZ, Maria Elvira; FígARI, Carlos Eduardo (orgs.). Prazeres dissidentes. Rio de Janeiro, Garamond, 2009, pp.309-341.

FARIAS, Juliana. Fuzil, caneta e carimbo: notas sobre burocracia e tecnologias de governo. Confluências: revista interdisciplinar de sociologia e direito, vol. 17, n. 03, Niterói, 2015, pp.75-91.

. Governo de mortes uma etnografia da gestão de populações de favelas no Rio de Janeiro. Tese (Doutorado em Sociologia e Antropologia), IFCS/UFRJ, Rio de Janeiro, 2014.

FELTRAN, Gabriel de Santis. Fronteiras de tensão: política e violência nas periferias de São Paulo. São Paulo, Editora UNESP; CEM; CEBRAP, 2011.

Margens da política, fronteiras da violência: uma ação coletiva das periferias de São Paulo. Lua Nova, n. 79. Rio de Janeiro. 2010, pp.201-233.

FRANÇA, Isadora Lins. Consumindo lugares, consumindo nos lugares: homossexualidade, consumo e subjetividades na cidade de São Paulo. Rio de Janeiro, EdUERJ, 2012.

GAGNON, John. Uma interpretação do desejo: ensaios sobre o estudo da sexualidade. Rio de Janeiro, Garamond, 2006.

HIRATA, Daniel Veloso. Sobreviver na adversidade: entre o mercado e a vida. Tese (Doutorado em Sociologia), FFLCH, USP, São Paulo, 2010.

HIRATA, Helena. Gênero, classe e raça: interseccionalidade e consubstancialidade das relações sociais. Tempo social: revista de sociologia da USP, vol. 26, n. 1, São Paulo, 2014, pp.61-73.

KERGOAT, Danièle. Dinâmica e consubstancialidade das relações sociais. Novos Estudos CEBRAP, vol. 86, São Paulo, 2010, pp.93-103. 
LACERDA, Paula Mendes. O sofrer, o narrar e o agir: dimensões da mobilização social de familiares de vítimas. Horizontes Antropológicos, vol. 20, Porto Alegre, 2014, pp.45-76.

. O "caso dos meninos emasculados de Altamira": polícia, justiça $e$ movimento social. Tese (Doutorado em Antropologia Social), Museu Nacional / UFRJ, Rio de Janeiro, 2012.

LEMOS, Diego José Souza. Contando as mortes de violência transhomofóbica: uma pesquisa sociojurídica dos processos criminais na cidade do Recife e uma análise criminológico-queer da violência letal. Dissertação (Mestrado em Direito), CCJ/UFPE, 2017.

MCClintock, Anne. Couro imperial: raça, gênero e sexualidade no embate colonial. Campinas, Editora da Unicamp, 2010. [Trad. Plínio Dentzien].

MISSE, Michel. Crime, sujeito e sujeição criminal: aspectos de uma contribuição analítica sobre a categoria "bandido". Lua Nova, n. 79. São Paulo, 2010, pp.15-38.

MOUTINHO, Laura. Diferenças e desigualdades negociadas: raça, sexualidade e gênero em produções acadêmicas recentes. cadernos pagu (42), Campinas, Núcleo de Estudos de Gênero-Pagu/Unicamp, 2014, pp.201-248.

Olivar, José Miguel Nieto. Devir puta: políticas da prostituição de rua na experiência de quatro mulheres militantes. Rio de Janeiro, EdUERJ, 2013.

OLIVEIRA, Luciano. Do nunca mais ao eterno retorno: uma reflexão sobre a tortura. $2^{a}$. ed. São Paulo, Brasiliense, 2009.

PISCITELli, Adriana. Trânsitos: brasileiras nos mercados transnacionais do sexo. Rio de Janeiro, EdUERJ, 2013 . Interseccionalidades, categorias de articulação e experiências de migrantes brasileiras. Sociedade e Cultura, vol. 11, $\mathrm{n}^{\circ}$ 2, Goiânia, 2008, pp.263-274.

PISCITELli, Adriana; LOWENKRON, Laura. Categorias em movimento: a gestão de vítimas do tráfico de pessoas na Espanha e no Brasil. Ciência e Cultura, vol. 67, n. 02, São Paulo, 2015, pp.35-39. 
Ruggiero, V. Crime and markets: essays in anti-criminology. Oxford, Oxford University Press, 2000.

. Securité et criminalité économique. In: KoKOREFF, M. et al. (orgs.). Economies criminelles et mondes urbains. Paris, PUF, 2007, pp.121-135.

Ruggiero, V.; South, N. The late-modern city as a bazar. The Britsh Journal of Sociology, vol. 48, n. 01, London, 1997, pp.54-70.

TELLES, Vera da Silva. Jogos de poder nas dobras do legal e do ilegal: anotações de um percurso de pesquisa. Serviço Social \& Sociedade, n. 115, São Paulo, 2013, pp.443-461.

. A cidade nas fronteiras do legal e do ilegal. Belo Horizonte, Fino Traço, 2010.

TELlES, Vera da Silva; HiRATA, Daniel Veloso. Ilegalismos e jogos de poder em São Paulo. Tempo Social: revista de sociologia da USP, vol. 22, n. 02, São Paulo, 2010, pp.39-59.

. Cidades e práticas urbanas: nas fronteiras incertas entre o ilegal, o informal e o ilícito. Estudos Avançados, vol. 21, n. 61, São Paulo, 2007, pp.173-191.

ThOMPSON, E. P. Senhores e caçadores. $2^{\text {a }}$ ed. Rio de Janeiro, Paz e Terra, 1997. [Trad. Denise Bottman].

. A formação da classe operária inglesa I: a árvore da liberdade.. Rio de Janeiro, Paz e Terra, 1987. [Trad. Denise Bottmann]

VIANNA, Adriana. Violência, Estado e gênero: entre corpos e corpus entrecruzados. In: SoUZA LiMA, Antônio Carlos de.; GARCIA-ACOSTA, Virgia (orgs.). Margens da violência: subsídios ao estudo do problema da violência nos contextos mexicano e brasileiro. Brasília, ABA, 2014, pp.209-237.

VIANNA, Adriana; FARIAS, Juliana. A guerra das mães: dor e política em situações de violência institucional. cadernos pagu (37), Campinas, Núcleo de Estudos de Gênero-Pagu/Unicamp, 2011, pp.79-116. 